\title{
調查報告
}

\section{クロアチア紛争後のコメモレーションによる ナショナル・アイデンティティの強化と継承}

\author{
Reinforcement and Transmission of National Identity \\ through Commemoration after the Croatian War
}

\author{
木戸 泉 \\ KIDO Izumi
}

\author{
（2019年10月 15 日受付 2020 年 1 月 14 日受理）
}

\begin{abstract}
バルカン半島西部に位置するクロアチアは，1990年代のクロアチア紛争を経て，多民族国家ユーゴスラヴィア から独立を果たした。紛争終結から 20 年以上が経過した現在, クロアチア国内では紛争の記憶を強固にし, さら に次世代へ継承しようとする動きが見られる，特に激戦地となった都市ヴコヴァルでは，クロアチア系住民の紛争 の記憶を強化し継承する行事の開催やモニュメントの設立が積極的に行われている. 本研究では, それらの表象内 容や設置主体を分析し，地域レベルと国家レベル，またナショナル・マジョリティとナショナル・マイノリティの 間で，紛争に対する受け止め方に差異が生じていることを明らかにしたそそしてこれを踏まえて， EU加盟を果た したクロアチアという国家のナショナル・アイデンティティをめぐるダブルスタンダードについて検討を加えるこ とができた。
\end{abstract}

The Republic of Croatia, located in the northwestern part of the Balkan Peninsula, became independent from the multiethnic state of Yugoslavia in 1991. Although more than 20 years have passed since the end of the armed conflict, Croatian officials are promoting a movement to reinforce memories of the war and transmit them to younger generations. The movement is especially popular in the city of Vukovar, once a site of violent clashes, where the ethnic Croatian population organizes various commemorative events and erects new monuments. Analysis of the symbolism of monuments and of the subjects depicted shows differences in attitudes toward the conflict at the local and national levels as well as between the national majority and minority populations. These differences clearly illustrate political double standards when it comes to the issue of national identity in Croatia, which joined the EU in 2013.

キーワード: クロアチア, コメモレーション, ナショナル・アイデンティティ, 紛争, 記憶, モニュメント Key words: Croatia, commemoration, national identity, conflict, memory, monument

\section{I はじめに}

1990 年代初頭，社会主義体制の国家が次々と解体 された。バルカン半島西部に位置したユーゴスラヴィ ア社会主義連邦共和国（以下，ユーゴスラヴィア）も その一つである，ユーゴスラヴィアは多様な民族から なる多民族国家であり，スロヴェニア，クロアチア， ボスニア・ヘルツェゴヴィナ, セルビア，モンテネグ ロ, マケドニアの六つの共和国と, いくつかの自治州 と自治区によって構成されていた．1980年の国家主 導者ティトーの死を契機に，社会主義のイデオロギー による市民統治が困難を極めるようになると, 各共和 国の民族が自民族中心の国家建設を目指し，連邦内の
共和国の独立を引き留めようとする，主にセルビア系 で構成されたユーゴスラヴィア政府と各共和国の間で 紛争にまで発展した．特にクロアチアとボスニア・へ ルツェゴヴィナでは, 1991 年から 1995 年まで続いた 紛争により，多くの犠牲者や難民を出し，その後の経 済にも大きな爪痕を残した。

ユーゴスラヴィアから独立したスロヴェニアととも に, クロアチアは2013年にEUに加盟を果たし，超国 家組織の経済・政治体制に組み込まれた，対外的な政 策の一方，国内では自民族中心的な政策が目立ち，一 部のナショナル・マイノリティの権利は確実に保護さ れているとはいえない状況も見られる。 また，同じく ユーゴスラヴィアから独立したセルビアやボスニア・ 
ヘルツェゴヴィナは現在EU加盟を目指しているが, 多民族国家であった歴史が生んだ民族や領土をめぐる 問題ゆえに, 最終的な加盟交渉前で足踏みをしている.

このような一連の民族をめぐる紛争を経て，新たな 独立国では紛争の記憶を維持して継承する動き，すな わちコメモレーション (顕彰行為) が目立っている. 中でもクロアチアではさまざまなコメモレーションが 確認できる. クロアチアの最東端, セルビアとの国境 に位置する都市ヴコヴァルVukovarは，クロアチア紛 争時に激しい戦闘があった場所であり，クロアチアに とって祖国を守った場所として，現在多くのコメモ レーションがなされている.

ところで, 戦争の記憶はナショナリズム研究で頻繁 に取り上げられるテーマであり，たとえばアンダーソ ン（2007）は『想像の共同体』の冒頭で,「これほど 近代文化としてのナショナリズムを見事に表彰するも のはない」として「無名戦士の墓と碑」を挙げてい る.ナショナリズムの想像力は死（そして不死）と大 いに関係があり，大量の同国民の死が，ひとりひとり の人間に同じ国民であることを想像させる，つまり 「国民的想像力」を大いに働かせる装置となっている という（アンダーソン 2007）。れはル・ゴフ (1999: 145）の言葉を借りれば，無名戦士の墓では「記憶は 匿名性の限界を超え，名もなき死者の遺骸を前にし て，共通の記憶における国民の団結が表明される」の である。モッセ（2002）は，市民宗教としての戦死者 の英霊祭祀という視点から, 大戦の戦死者が英霊とし て祭り上げられる背景と過程を, その著, 『英霊』で 明らかにした。そこでは, 戦士の墓地は国民的崇拝の 地となるように計画的に作られ，特にドイッでは国民 意識を醸成するために重要な役割を担い, 戦後も墓地 への巡礼や儀式によって死者の記憶を維持し続けてい たと論じている.

一方，アメリカ合衆国でも公的記憶の創造における 戦争の役割は歴史学者らによって大いに議論されてい る.たとえばボドナー（1997）は，ベトナム戦没記念 碑をめぐる戦争参加者と国民国家の擁護者の二つの対 立を,「公的記憶」の創造される中での公的利害と個 別民衆的な利害の錯綜として描いた。また，スターケ ン（2004）は集合的記憶とは異なる「文化的記憶」と いう言葉を編み出し, ベトナム戦争とエイズ・キルト
を文化的記憶から分析することで，だれがアメリカ国 民となれるのか論じた，さらに日本の研究者では，粟 津 (2000: 199, 2006) が，戦争記念碑は近代国家が戦 争による大量死を表象し, 解釈したものであるとし, その解釈の形成過程をイギリスの戦没記念碑と沖縄の 戦没者記念施設を通して分析している。 また和田（2005） は，アメリカ独立革命に関する記念碑に着目し，ベト ナム戦争などと異なり，異論のない「正統」な存在で あるアメリカ独立革命の史実が, 記念碑の設立によっ て再生産・再構成されることで, アメリカの伝統が創 造されたと述べている.

このように，戦没者記念墓地や慰霊碑の建立は，国 民国家が膨大な過去の戦争記憶の中から一部を選択し 解釈した現象であり，それは現在の立場から未来に向 けた国家の在り方を表明する現象となっている。 そし てこれらに接することによって，人々は国民国家のた めに命を捧げた兵士とのつながりを強く感じることが でき，同じ「想像の共同体」に所属しているという意 識を強めるのである.

しかし, 以上のような戦争記憶とコメモレーション の研究では, マジョリティとマイノリティの両面から の検討が十分になされていない.つまり, 多くの研究 で論じられている国家による戦争記憶の戦略的利用 は，基本的に国家のマジョリティに受け入れられてい くものである.もちろん, マイノリティの人々が, 戦 争記憶の統合によって「一つの国民である」という意 識をもつケースもあろう。しかし，国家による意識統 合には相容れないマイノリティがいることも事実であ る。

スターケン（2004: 35）のように，文化的記憶に基 づく国民の「想像の共同体」におけるマイノリティの 差異化・排除の問題を指摘した研究があるものの, ナ ショナル・マジョリテイと異なる属性（エスニックな ど）をもったナショナル・マイノリティの肩身の狭さ について論じる研究はいまだ少ない，排除され取り残 されたマイノリテイが国民的記憶に感じる違和感も指 摘することによって, 戦争記憶と国民国家の関係につ いての議論をさらに深めることができるだろう。その ためにも，埋もれてしまいがちなマイノリティの声や 彼らの小さな記憶に対する実践をフィールドに基づい て記述することが重要である（粟津 2006: 114）。ナ 
ショナル・マジョリテイとナショナル・マイノリティ の紛争記憶に関するコメモレーションを検討すること によって，その国のナショナル・アイデンティティの 有様も見えてくるのである.

そこで本研究は, クロアチアにおける戦争記憶の表 象, 特にヴコヴァルで行われているコメモレーション に着目し，エスニックマジョリティであるクロアチア 人とエスニックマイノリティであるセルビア人にどの ように受け止められているか，そしてコメモレーショ ンがいかにナショナル・アイデンティティの強化と継 承をもたらしているかを明らかにすることを目的とす る。

コメモレーションには記念碑や記念館, 記念行事な どが該当する，本研究では，特に記念碑の分析に際し ては，フット（2002）の景観分析方法を援用する. フットは, アメリカ合衆国における暴力や悲劇の現場 の景観を四つの類型（聖別，選別，復旧，抹消）に分 類し，アメリカ人がその現場をどのように表象するか は，社会的・集合的記憶と関係しており，景観やそこ にある記念碑はその耐久性・永続性をもつ特性ゆえ に，長期的な集合的な価值観を象徵するものであると した。また，いまだにコンセンサスが得られていない ために何らかのコメモレーションがなされていない場 所は，その存在自体が公的意味合いや社会的記憶をめ ぐる一種の集団的な曖昧さを表していると指摘した. この指摘は, 聖別や選別のコメモレーションだけでな く，抹消という今まで議論されていなかった景観に焦 点を当てたからこそ見えてくるものと考えられる．こ の点で, こうした景観の分類は, ヴコヴァルにおける ナショナル・マジョナリティとナショナル・マイノリ ティの紛争をめぐる考え方の違いを明らかにすること に有効であろう.

以下では，まずクロアチア国内の多民族性を歴史 的，地理的に簡単に俯瞰したのち，民族構成に着目し ながら 1990年代のクロアチア紛争の経緯を概観する. つぎに, ヴコヴァルで現在行われている紛争関連のコ メモレーションとしての記念碑, 記念館, 記念行事の 分析を行い，可視化されたヴコヴァルのコメモレー ションに対するナショナル・マジョリティ内での紛争 に対する受け止め方が，ナショナル・マジョリテイ内 部においても，またナショナル・マジョリティとナ
ショナル・マイノリティ間においても差異がみられる 点を指摘し，これと連動するクロアチアのナショナ ル・アイデンティティについて考察する.

なお，本稿における国民と民族の呼称について説明 しておく，セルビア国籍をもちセルビアのアイデン ティティをもつ者はセルビア人，クロアチア国籍をも ちセルビアのアイデンティティをもつ者はセルビア系 住民，国籍を問わずセルビアのアイデンティティをも つ者はエスニック・セルビア人を呼ぶこととする．同 様に, クロアチア国籍をもち, クロアチアのアイデン ティティをもつ者はクロアチア人とし，国籍を問わず クロアチアのアイデンティティをもつ者はエスニッ ク・クロアチア人とする。なお，クロアチアの国籍を もつ者の総体はクロアチア国民とする.

\section{IIクロアチアの多民族性と紛争の経緯}

\section{1.クロアチア概要}

クロアチアはバルカン半島西部に位置し, 面積 $56,542 \mathrm{~km}^{2}$ (九州の約 1.5 倍), 人口約 428 万人を擁す る。1991年にユーゴスラヴィア社会主義連邦共和国 より独立し，2013年にEU加盟を果たした 。国内は 四つの地域からなり，首都ザグレブが位置する中央ク ロアチア，その東，ハンガリー平原に広がるスラヴォ ニア，西端に位置するイストリア，アドリア海に沿っ て南に伸びるダルマティアがある（図1)。ザグレブ に製造業やサービス業が集中する一方，イストリアと ダルマティアの沿岸部には歴史都市が立地することか

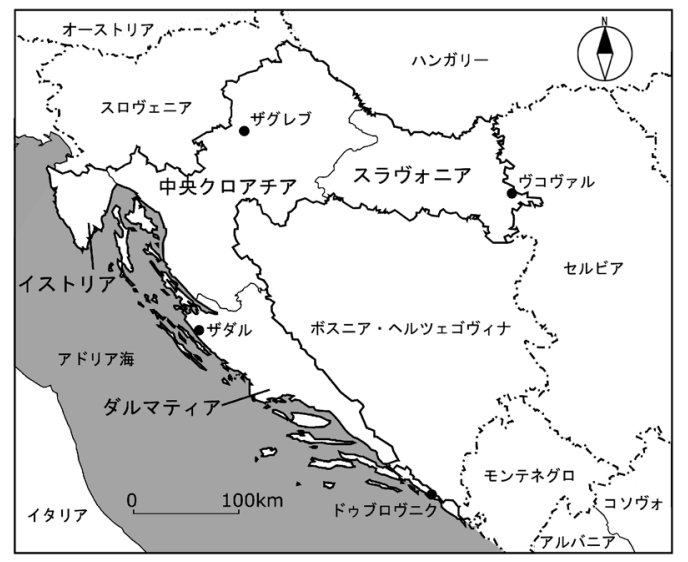

図1 四つの地方からなるクロアチア

Fig. 1 Republic of Croatia and its four main regions 
ら，夏のバカンスを過ごす多くの観光客が訪れ，観光 業が重要な産業になっている。このほか, 沿岸部の造 船業や石油化学工業も重要な産業部門になっている. これに対して，スラヴォニアは農業地域であり，小麦 やトウモロコシの栽培が盛んだが，人口の流出が目立 ち，経済的には停滞傾向にある。

2. クロアチアの多民族性と紛争

1）多民族地域の形成

現在, クロアチアを構成する主要民族はクロアチア 人である．国内の総人口に占めるクロアチア人の割合 は，独立後ゆるやかに上昇し，2011年の国勢調査で はついに総人口の $90 \%$ 以上を占めるまでになった. 一方, 最大のナショナル・マイノリティはセルビア系 住民である。 クロアチア人が増加するのとは逆に, 年々その数は減少しており，2011年の国勢調査では 総人口の $4.4 \%$ となっている（表 1$)$. これに次いで, ボシュニャク系住民（ムスリム），ハンガリー系住民， イタリア系住民など 22 のナショナル・マイノリティ がいる2).

そもそもクロアチア人は，7世紀頃にバルカン半島 に定住したスラヴ人のうち，内陸部のパンノニア地方 や沿岸部のダルマティアに住み着いた人々に由来す る。925年に統一国家がつくられ，ローマカトリック を受け入れながら以後 200 年にわたって王国を維持し 続けた。 11 世紀に最盛期を迎え，当時の繁栄ぶりは 叙事詩などによってのちの時代に伝えられている. そ の後, 彼らの国家は消滅し, 以後, 20 世紀に至るま
でハプスブルク帝国およびその後継国の支配下に置か れ，オスマン帝国との国境地域となった。しかし，中 世に繁栄した王国の記憶は近代のナショナリズムの時 代に頻繁に持ち出され，独自の国家をもつことがクロ アチア人の悲願となった ${ }^{3)}$.

一方, クロアチアの東隣に居住するセルビア人は, 同じスラヴ人ながらセルビア正教会の信仰を選択した 人々に由来する，彼らは中世に独自の国家を建設した が，コソヴォの戦い（1389年）の敗北を契し，オス マン帝国の支配下に入った。以来，その支配は20世 紀初頭まで続いた。こうしてクロアチアとセルビア は，ハプスブルク帝国とオスマン帝国それぞれの最前 線として長く対峙し続けてきた。それがのちのクロア チア紛争で最大の争点となる「セルビア人問題」へと 発展してゆく.

19 世紀後半になると，これらの人々の間には民族 自決の機運が高まり，南スラヴ人（ユーゴスラヴ）に よる国家建設が模索されるようになった．第一次世界 大戦によってこの二つの帝国が崩壊すると，セルビア 人国王を国家元首に掲げた「セルビア人・クロアチア 人・スロヴェニア人王国」，いわゆる「第一のユーゴ スラヴィア」が誕生する。ただし，七ルビア人国王の 独裁体制に他の民族の反発が起こり，国内の混乱は絶 えなかった。それは第二次世界大戦時の壮絶な「兄弟 殺し」4) へと発展していく．大戦後，パルチザンで活 躍したティトーを中心とした社会主義体制の「第二の ユーゴスラヴィア」によって，この対立は当面抑え込 められ，「第二のユーゴスラヴィア」では自主管理体

表1 ヴコヴァルおよびクロアチアにおける民族構成

Table 1 Populations of Vukovar and the Republic of Croatia by ethnic group

\begin{tabular}{|c|c|c|c|c|c|c|c|}
\hline \multirow{2}{*}{ 地域(面積) } & \multirow{2}{*}{ 民族 } & \multicolumn{2}{|c|}{1991} & \multicolumn{2}{|c|}{2001} & \multicolumn{2}{|c|}{2011} \\
\hline & & 人口(千人) & 割合 (\%) & 人口(千人) & 割合(\%) & 人口(千人) & 割合 (\%) \\
\hline \multirow{4}{*}{$\begin{array}{c}\text { ブコヴァル市 } \\
\left(100.26 \mathrm{~km}^{2}\right)\end{array}$} & クロアチア人 & 36.9 & 43.8 & 18.2 & 57.5 & 15.9 & 57.4 \\
\hline & セルビア系住人 & 31.4 & 37.3 & 10.4 & 32.9 & 9.7 & 34.9 \\
\hline & その他 & 15.8 & 18.8 & 3.1 & 9.7 & 2.1 & 7.8 \\
\hline & 総計 & 84.2 & 100.0 & 31.7 & 100.0 & 27.7 & 100.0 \\
\hline \multirow{4}{*}{$\begin{array}{c}\text { ブコヴァル・スリイェム郡 } \\
\text { ヴコヴァル市を除いた4都 } \\
\text { 市、 } \\
\text { 26地方自治体 }\end{array}$} & クロアチア人 & & & 142.1 & 82.1 & 126.3 & 83.2 \\
\hline & セルビア系住人 & & & 21.2 & 12.3 & 18.2 & 12.0 \\
\hline & その他 & & & 9.8 & 5.7 & 7.4 & 4.9 \\
\hline & 総計 & & & 173.1 & 100.0 & 151.8 & 100.0 \\
\hline \multirow{4}{*}{$\begin{array}{c}\text { ブコヴァル・スリイエム郡全 } \\
\text { 域 } \\
\left(2,454 \mathrm{~km}^{2}\right)\end{array}$} & クロアチア人 & & & 160.3 & 78.3 & 142.1 & 79.2 \\
\hline & セルビア系住人 & & & 31.6 & 15.5 & 27.8 & 15.5 \\
\hline & その他 & & & 12.8 & 6.3 & 9.6 & 5.3 \\
\hline & 総計 & & & 204.8 & 100.0 & 179.5 & 100.0 \\
\hline \multirow{4}{*}{$\begin{array}{c}\text { クロアチア全域 } \\
\left(56,542 \mathrm{~km}^{2}\right)\end{array}$} & クロアチア人 & $3,736.4$ & 78.0 & $3,977.2$ & 89.6 & $3,874.3$ & 90.4 \\
\hline & セルビア系住人 & 581.7 & 12.2 & 201.6 & 4.5 & 186.6 & 4.4 \\
\hline & その他 & 466.2 & 9.6 & 258.7 & 5.8 & 223.9 & 5.2 \\
\hline & 総計 & $4,784.3$ & 100.0 & $4,437.5$ & 100.0 & $4,284.9$ & 100.0 \\
\hline
\end{tabular}


制や緩やかな連邦制を敷くことで，民族の枠組を超え た国家が構築された。しかし，ティトー亡き後は，国 内における経済の南北格差が解消されていないことを 背景に, セルビア人の有意な立ち位置に不満もあっ て，各構成共和国でユーゴスラヴィアの政治体制に反 発する民族主義的な指導者が現れるようになった．特 にクロアチアは，経済水準が高く南部の経済状況に不 満をもつスロヴェニアと足並みを揃えて，ユーゴスラ ヴィアからの独立を目指していく.

2）クロアチア独立と紛争

クロアチアでは, 1991 年に始まったクロアチア独立 紛争 (以下, クロアチア紛争) を「祖国戦争 Domovinski rat」と呼んでいる。現在, クロアチアでは「祖国戦 争」専用の歴史教科書がつくられており（Barič et al. 2015)，多くの時間を割いて授業が行われている。 ク ロアチア紛争は, クロアチア人の民族主義者トゥジマ ン $^{5)}$ によるクロアチアの国土回復・国土維持のための 重要なプロセスであり, クロアチア人側から見た戦争 記憶自体が彼らにとって重要なアイデンティティの要 素の一つとなりえた，そして記憶が風化されることの ないよう，維持と継承のための努力がなされている.

クロアチア紛争の経緯は, ユーゴスラヴィアの一部 を構成していた 1990 年 5 月，トゥジマンが右派政党の クロアチア民主同盟（HDZ）を率い，クロアチア共 産主義者同盟との選挙で勝利したことにさかのぼる. 彼は筋金入りの民族主義者であり，民族自決に基づい た「分離独立をも含めた，歴史的・自然境界における 全クロアチア人の純粋・不可分な自決権」を主張して いた（月村 2001: 17).

彼は1990年にクロアチア社会共和国幹部会議長 (のちの大統領) に選出され, クロアチアの今後の重 要課題 10 項目として, 新憲法制定や, EC加盟を意味 するクロアチアのヨーロッパの仲間入りと国内のヨー ロッパ化などで挙げ (月村 2006: 35), 同年 12 月 22 日 にはクロアチア共和国憲法（クリスマス憲法）を制定 した。前文には，7世紀のクロアチア王国にさかのぼ る歴史が書かれ，本文には国民を構成する民族として クロアチア人のみが明記された。 また，公用語はクロ アチア語, ラテン文字のみの使用が規定され，セルビ ア系住民が用いるセルビア語とキリル文字は無視され た (久保 2003: 160) ${ }^{6)}$.
1991年5月に行われた独立を問う国民投票の結果 （賛成票94\%）を受けて，同年6月にクロアチアはス ロヴェニアと共に独立を宣言し，翌1992年1月にEC が両国の独立を承認した。しかし，国内ではセルビア 系住民が自治を求めて団結を始め, クロアチア人との 衝突が頻発した。 またユーゴスラヴィアはクロアチア の離脱を承認せず，クロアチアに住むセルビア系住民 の保護に向けて, 着々と軍備を整えていた.

クロアチアのセルビア系住民は，スラヴォニア東部 と中央クロアチア東部にまとまった数で分布してい る. 特に中央クロアチアのセルビア系住民は, クリス マス憲法制定直前の 1990 年 12 月 21 日，「クライナ・ セルビア人自治区」の創立を宣言し，代表のバビッチ は「クロアチア人が排他的に自分の国家をつくろうと している」としてクロアチア当局を非難した（久保 2003: 167).ここでは, 住民の半数以上がセルビア系 住民で占められていた。一方, クロアチア東部のセル ビア系住民もこの動きに同調して「スラヴォニア・バ ラニャ・西スレム・セルビア人自治区」を設立した. しかし，ここではセルビア系住民は地域人口の3割強 の規模にすぎなかった。これがユーゴスラヴィアを構 成するセルビア勢力にとって，「純然たるセルビア系 住民地域をつくる」ための侵略と，「民族浄化」を正 当化する根拠となった $(\text { 久保 2003: 165 })^{7)}$. 1991年 5 月に行われたクロアチア中部と東部のセルビア系住民 が多く住む地域での投票を経て，クロアチアの国土約 3 分の 1 を占める「クライナ・セルビア人共和国」が セルビア系住民によって一方的に創設された。この共 和国は国際社会で認められることはなかったが，その 後のクロアチアにおける「セルビア人共和国」の問題 であり続けた．1995 年 5 月，クロアチア軍による西ス ラヴォニア地域で「閃光作戦」と, 同年 8 月のクライ ナ地域での「嵐作戦」が行われると,「共和国」内の セルビア系住民は国外に追放され，「共和国」は解体 された。これによりクロアチアは国土をほぼ回復し， 同時にセルビア系難民・避難民が大量に出る結果と なった。

1995 年 12 月のデイトン合意により，クロアチア紛 争は終結した。なお，セルビア系住民が支配した東部 地域は紛争終結後も維持されて国連軍（UNTAES）の 管轄となっていたが，1998年1月クロアチアに平和裏 
に返還され，これによってクロアチアは独立当初の国 土を回復した。

クロアチア当局によると，兵士や市民など少なくと も19,500 人が紛争により死亡もしくは行方不明であり， 35,078 人が負傷したとされている（負傷者数には国連 平和維持軍 78 人, ユーゴスラヴィアの兵士 613 人も含 む).クロアチア各地が戦場となったが, 中でもクロ アチア紛争最大の激戦で知られるヴコヴァルの戦いで は，最も多くのクロアチア人犠牲者が出た。また，ヴ コヴァルの戦いは，セルビア勢力が主体のユーゴスラ ヴィア人民軍（以下，JNA）がクロアチアで初めて主 体的に関わった戦いであり, クロアチア紛争の象徵と なったという点でも重要である（月村 2006: 68）.

\section{3. ヴコヴァルの戦い}

本稿の調査地であるヴコヴァル市（以下，ヴコヴァ ル）はクロアチア独立紛争の激戦地の一つであり, ヴ コヴァルにおける一連の戦闘はヴコヴァルの戦いと呼 ばれている．現在ヴコヴァルは，クロアチア系住民に とって「犠牲と抵抗の象徴」の町になっている.

1）民族対立の場としてのヴコヴァル

ヴコヴァルは, クロアチア東部のスラヴォニアに あるヴコヴァル・スリイェム郡の郡都である（面積 $100.26 \mathrm{~km}^{2}, 2011$ 年の人口 27,683$)$. ヴコヴァルの戦い によって，約 22,000 人が住む場所を追われたため，人 口は84,189人（1991年）から31,670人（2001年）へ と大幅に減少し，その後も減少の一途をたどってい る. ヴコヴァルは，ドナウ川に面していることからク ロアチア最大の河港を擁するが, 紛争後はかつてあっ た活気を失っている。現在の主要産業は, 広大なハン ガリー平原南部に位置することから，小麦やワイン用 ブドウ栽培, 畜産業である. 2011 年時点でのヴコ ヴァルの失業率は $35 \%$ と, 全国平均に比べて高い.

民族別に見るとクロアチア系住民が 15,881 人（人口 比率約 57\%), ついでナショナル・マイノリティのセ ルビア系住民が9,654人（約 35\%）となっており，こ のほかにハンガリー系住民などのマイノリティがいる (2011年).一帯はクロアチアの他の地域に比べて, セルビア系住民が比較的多く居住している地域であ り，ヴコヴァル・スリイェム郡の基礎自治体 ${ }^{8)}$ には人 口の約9割をセルビア系住民が占める地区もある。
この地域に比較的多くのセルビア系住民が居住して いるのは，かつて大規模な入植活動が行われたからで ある. その第一波は, 16 世紀後半からハプスブルク 帝国支配下の軍政国境地帯で起こった．対オスマン帝 国の防衛ラインとして設定されたこの軍政国境地帯に は, いわゆる屯田兵が入植し, 帝国内各地からの入植 が進められた（石田 2003）。第二波は，第二次世界大 戦後にドイツ人が国外に追放されたあとに入植したセ ルビア人農民である．彼らは第二次世界大戦中にパル チザンとして活躍したため, 戦後その処遇が配虑され たのである。

この地域でのクロアチア人とセルビア系住民をめぐ る摩擦が大きくなったことについては, 第二波のセル ビア系住民の入植以来のクロアチア系住民との共存の 歴史が浅く，それゆえに紛争がより激しいものになっ たとの見解もある (定形 2001 $)^{9)}$.

1980 年代後半にクロアチア民族中心主義の政策が 次々と打ち出されるようになると，ヴコヴァルの人口 の約 3 割を占めるセルビア系住民が自治を要求し, こ れに対してクロアチア人が彼らの存在を疎ましく考え るようになったというわけである.

2）ヴコヴァルにおける戦闘

ヴコヴァルは戦略上の要衝として, クロアチア軍と JNA双方にとってきわめて重要な場所とされた。 1980 年代にクロアチアの独立の動きが出始めた頃から， ヴ コヴァルでもクロアチア人とセルビア系住民の間の緊 張は徐々に高まり，かつてあった平穏な共生は困難に なった。1991年8月25日にドナウ川を越えてヴコ ヴァルに進攻したJNAは，周囲の道路を封鎖してヴ コヴァルを完全に包囲し，その後3カ月にわたるクロ アチア軍による抵抗もむなしく11月18日にヴコヴァ ルは陥落した，市街地は徹底的に破壊され，歴史ある バロック建築も甚大な被害を受けた ${ }^{10)}$.

その後, この地域はJNAが支配し, クロアチア国 内の他地域や同じ時期に紛争中のボスニア・ヘルッェ ゴヴィナから逃れてきたエスニック・セルビア人が流 入した。

クロアチア紛争では, 各地で衝突や虐殺が発生した. 中でもヴコヴァル陥落直後に起こったオヴチャラの虐 殺は, クロアチア紛争において最大規模のものであっ た。ヴコヴァル市立病院の医療従事者と病院に収容さ 
れていた負傷者ら数百人がJNAによって郊外のオヴチャ ラ農場に連れ出され，そこで殺害されたのである. 2008 年のヴコヴァル市立病院の発表によると, この虐 殺による犠牲者数は身元が判明した者で 211 人にのぼ り，55 人が行方不明のままである（Croatian Homeland War Memorial and Documentation Centre 2011: 135). 才 ヴチャラの虐殺がクロアチア人にとって今なお忘れが たい戦争記憶となっていることは，ザグレブにあるク ロアチア祖国戦争メモリアル・ドキュメンテーション センター（以下，ドキュメンテーションセンター）が 編纂・発行した紛争の資料に,「クロアチア共和国の 自由と独立のための苦難の象徵」と記されていること からもうかがえる（Nazor 2011: 223）.

2007 年のクロアチア当局の統計によると, ヴコヴァ ルの戦いで少なくとも 1,739 人が死亡した（うち，子 ども 89 人). 彼らの遺体は, ヴコヴァル・スリイェム 郡各地にある52の「集団墓地」やそれ以外の場所に 埋められ, 紛争後の発掘調査で 1,717 人の身元が判明 している（2007年現在）。ヴコヴァル第204旅団では, 879 人が死亡もしくは行方不明, 777 人が負傷した. 一方, ヴコヴァルの戦いによるユーゴスラヴィア側の 死者は, クロアチアの発表では 5,000 人から 15,000 人 とされているが，セルビアの発表は 1,200 人ほどと なっており，犠牲者数の見解は大きく分かれている (Croatian Homeland War Memorial and Documentation Centre 2011: 72).

また，この戦いではヴコヴァルのセルビア系住民も 犠牲者を出ていることに注意したい. クロアチア人犠 牲者とは異なり, セルビア系住民の犠牲者数は現在も 正確には把握できておらず，また行方不明のままとなっ ている者も多い。セルビア系住民への聞取り調査によ れば，戦前に 50 人，戦時中に 150 人ものセルビア系住 民がクロアチア系住民により殺害されたという ${ }^{11)}$.

ところで，ヴコヴァルの戦いで多大な犠牲者が出た ことについて，新生国家クロアチアの思惑をあげてお く必要がある。 クロアチア軍は, JNAがクロアチア国 内にある二つのセルビア人地区，すなわち東部のスラ ヴォニア地域と西部のクライナ地域を連結されようと するのに対して，これを阻止するためにJNAの戦略 拠点であるヴコヴァルへの攻撃を強めた．しかし，そ の一方で, クロアチア政府は他地域での兵力増員や武
器調達，また国家の国際的承認を受けるための外交努 力に力を注いでいた（Nazor 2011: 223，224）。そのた め, ヴコヴァルの戦いは長期化し，多大な犠牲を払う ことになった。いわば, ヴコヴァルは「捨て駒」的な 役割を果たしたのである。ただ，ヴコヴァルの惨状が マスメディアを通じて世界に発信されると，JNAの残 虐な行為への非難とクロアチアへの同情を呼ぶことに なった。

ヴコヴァルの多大な犠牲のもとでJNAによるクロア チア侵略は阻止された。その結果, ヴコヴァルはクロ アチア全土の防衛の象徴的な場所となった。 ドキュメ ンテーションセンターには,「(ヴコヴァルにおける) クロアチア防衛者は, 彼らの愛国心と勇気によって, クロアチアの歴史における栄誉ある地位を獲得した」 と記されている（Nazor 2011: 224）。

4. 紛争後のクロアチアにおける民族構成

紛争終結後, クロアチアの人口は, 多くの犠牲者や 難民が発生したことによって大幅に減少した。 それと 同時に，民族構成も大きく変化した．紛争終結後，初 めて行われた 2001 年の国勢調査では, クロアチア人が 人口の9割近くに達した一方で, 以前はクロアチアの 主要民族を構成していたセルビア系住民は $12 \%$ から 4.5\%へと著しく減少した。これは，クロアチア軍に よるセルビア系住民居住地域の掃討作戦がなされたこ とが大きな理由だが, 高揚するクロアチア・ナショナ リズムに身の危険を感じて国外へ逃亡したセルビア系 人難民がかなりの数にのぼったことも理由とされる.

\section{III ヴコヴァルにおける紛争のコメモレーション}

この章では，ヴコヴァルで見られる紛争に関するコ メモレーションの内容と意味を, クロアチア国内にお けるクロアチア人とセルビア系住民という二つの民族 の立場から検証していく．ここで対象とするコメモレー ションは, 記念碑, 記念館, 記念行事である. なお, 記念碑と記念館は，主に「ヴコヴァルにおける祖国戦 争メモリアルセンター」(以下，メモリアルセンター) が管理・管轄内であり，ヴコヴァルの戦いに関するも のと認識されていることから分析の対象とする. 
1. 対象とする記念碑の検討

ヴコヴァルでは，市内を中心に多くの記念碑が設置 されている(図2)，いうまでもなく，この一帯が紛争・ 虐殺の現場だからである。記念碑に永続性が伴うこと はアルブヴァクスやフットが指摘する通りであり ${ }^{12}$, ヴコヴァルにおける記念碑もその永続性ゆえに紛争時 の記憶を現在にとどめる装置となっている，紛争後， 記念碑がさまざまな場所に設置されることによって， ヴコヴァルは「祖国戦争を象徵する場所」として空間 的な広がりをもち，町全体が「記憶の場」になってい るように思われる ${ }^{13)}$.

そこで，主な記念碑を整理し，各記念碑の立地条件 や設置の意図を検討し, 記念碑個別の特徵からさらに は紛争を象徵する空間的な広がり, クロアチア人の記 憶を形成する「記憶の場」となっていることを示す. 具体的にはメモリアルセンターの管轄下である記念碑 と戦跡のうち, 比較的規模の大きなもの七つを挙げる.

1）ルジャツの十字架

ルジャツの十字架は, ヴコヴァル市街地から「ヴコ ヴァル第204旅団通り」沿いに郊外へ向かった場所に ある。設置年は不明である。1991年 11 月 2 日にJNA
に占拠されたルジャツでは，兵士と市民あわせて 59 人が殺害された.ルジャツの占領は，のちのJNAに よるヴコヴァル陥落における足掛かりとなっている。

十字架の土台には, 犠牲となった人々の氏名と共 に，「1991年11月 2 日のセルビアの侵略における，ル ジャツの69名の市民の悲劇的な死の記憶に」という 碑文が書かれている.

2）ボグダノヴツィの記念碑

ボグダノヴツィは，ヴコヴァル近郊にある人口 1,960 の小さな基礎自治体である，そのうちクロアチア人は 1,231 人で全体の $69 \%$ を占めている. 1991 年に 59 人の クロアチア人の兵士と市民がここで殺害された。記念 碑は, 2006年に地区の中心地にあるカトリック教会の 前に建てられた。この記念碑には, 他の記念碑と異な り，1990年代のクロアチア紛争での犠牲者だけでなく, 第二次世界大戦での地区の犠牲者の氏名も並べて書か れている，記念碑の中央には堂々としたキリスト像と 碑文があり，向かって左には第二次世界大戦で亡く なった 57 人の名前が, 向かって右にはクロアチア紛 争で亡くなった 128 人の名前が書かれている（図3). クロアチアの伝統的な組み紐文様であるプレテルの装

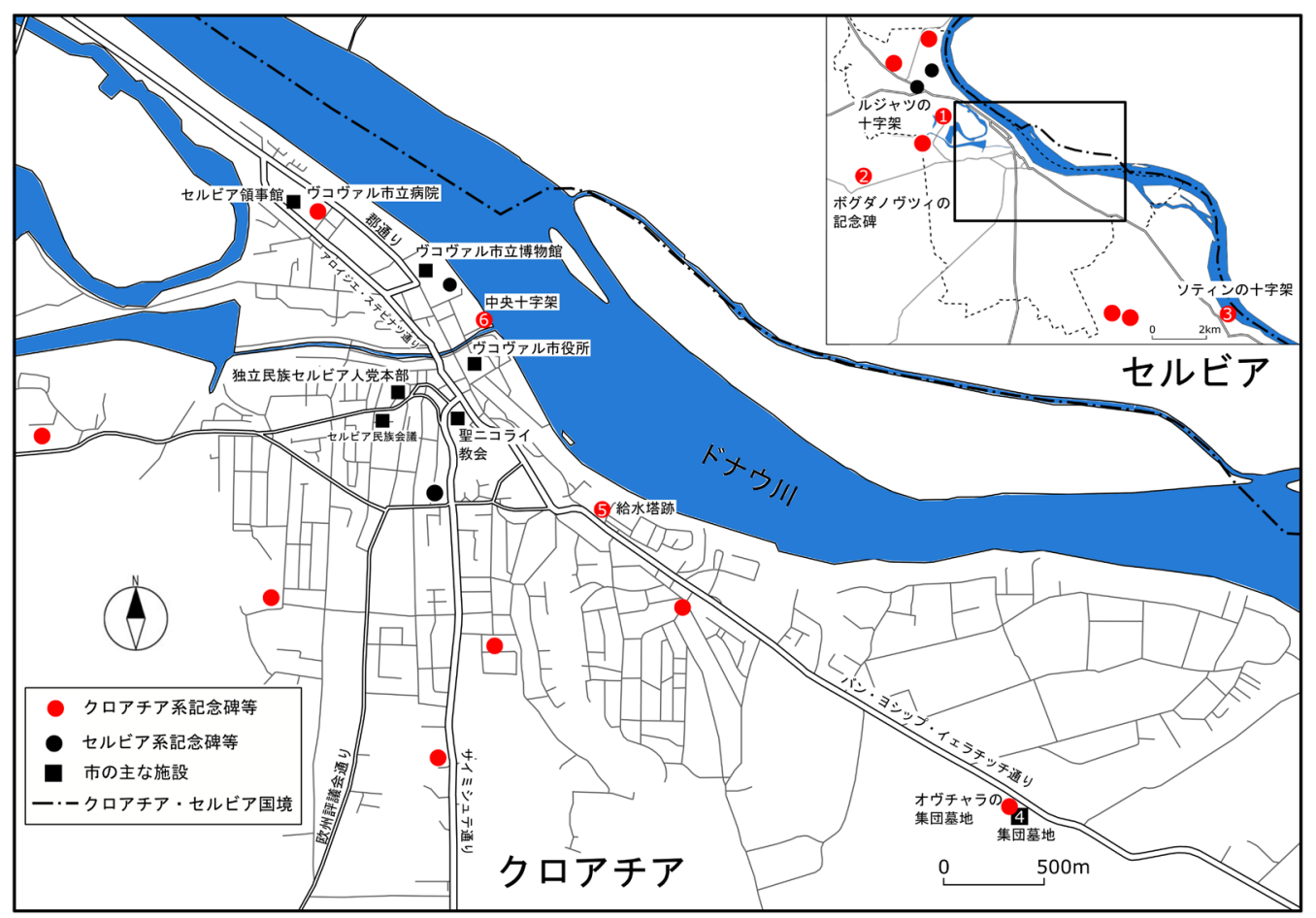

図 2 ヴコヴァル中心地における記念碑の分布（数字は本稿に登場する施設）

Fig. 2 Distribution map of monuments in the city center of Vukovar 
飾がなされている中央の碑文には，まず第二次世界大 戦時のパルチザンやチェトニクで起きた蛮行が書か れ，つぎに「セルビアのクロアチア侵略で悪事が再び 繰り返された」として，1990年代の紛争時のJNAと国 内外のチェトニク ${ }^{14)}$ の蛮行が記されている.つまり, この記念碑は，それぞれ時代の異なる二つの戦争の犠 牲者を, セルビアの侵略と蛮行により犠牲となったと いう点で結びつけ, 戦争の共通性と一貫性を示してい る.

\section{3) ソティンの記念碑}

ヴコヴァルのソティン地区がJNAに占領されると， 1991 年 10 月 14 日から 20 日にかけて, この地区のセル ビア系以外の住人はJNAによって近隣のネゴスラヴ ツィの強制収容所へ連行され，拷問や尋問を受けた。 また，残る人々も強制労働をさせられた。連行された 人々の多くは，殺害されるか行方不明のままになって いる.

ソティンの記念碑は地区のメインストリートである 「フラニョ・トゥジマン通り」に面した場所に設置さ れている。磔刑のキリスト像が揭げられている十字架 （碑文とクロアチア紋章が彫られている）の前に, 犠 牲者 59 人の名前と生没年の書かれた透明のプレート が60枚並べられている。磔刑像は 2001 年につくられ， プレートはメモリアルセンター職員の聞き取りによる とソティンの住民によって 2015 年 10 月 14 日に設置さ れた。プレートの1枚目の碑文では，犠牲者たちは 「私たちの祖国クロアチアの基礎に自分の人生を捧げ た」と書かれている。また，プレートには「あなたた ちが持っている誠実の旗が重いならば，私たちの骨が

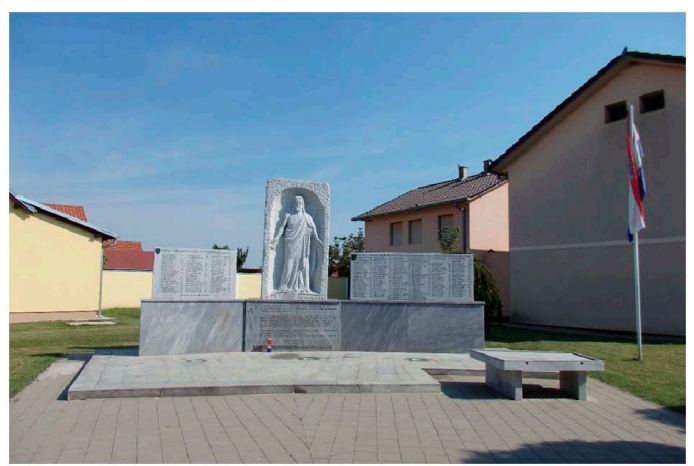

図3 ボグダノヴツイの記念碑 (2016年9月 4 日撮影)

Fig. 3 Monument to Bogdanovci
埋められている地面にそれを挿しなさい，私たちが支 えます」という死者側の言葉も添えられている.

4）祖国戦争犠牲者のための記念墓地

記念墓地は，ヴコヴァル市街地から「パン・ヨシッ プ・イェラチッチ通り」を南東方向へ $5 \mathrm{~km}$ ほど進ん だ郊外にある。ここはヴコヴァル最大の市民墓地であ り，ヴコヴァルの戦いで犠牲となった人々が埋葬され ている，毎年 11 月 18 日の犠牲者追悼記念式典（以下, 記念式典）では, 市内の市立病院からこの記念墓地ま で歩き, 中央記念碑の前で式典が行われる。

正門から進むと放射線状に墓が並んでおり，その中 心を貫く道の先に大きな中央記念碑が立っている（図 4)。中央記念碑はザグレブの彫刻家が設計し，2000年 8 月 5 日に退役軍人省によって設置された高さ $4 \mathrm{~m}$ の 巨大なブロンズ製の碑である。この記念碑には十字の 切れ込みが入っており，十字架とヴコヴァルの犠牲者 を表している（Marič 2005: 39）。中央記念碑の背後に は938本の白い十字架が並んでおり，この本数はヴコ ヴァル市内や周辺にあった 13 力所の「集団墓地」か ら掘り起こされた遺体の数を示している。この十字架 は，そこに死者が埋葬されているわけでも，死者の名 前が明記されているわけでもない。記念式典の日に は，十字架ひとつひとつに小さなクロアチア国旗とロ ウソクが供えられる。この白い十字架は犠牲となった 人々の数を視覚的に示す記念碑としての機能を果たし ている.

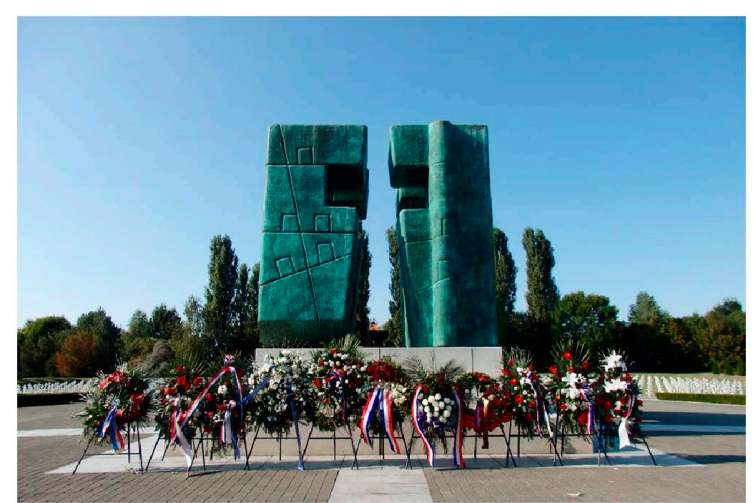

図4 記念墓地にある中央記念碑と白い十字架 (2016年 8 月 31 日撮影)

Fig. 4 Central monument and white crosses in the Memorial Cemetery 


\section{5）給水塔跡}

戦争遺跡の一つである (図 5)。1968 年のユーゴスラ ヴィア時代に建てられ, その高さと容積から, 当時は この種の施設の中ではヨーロッパ最大であった。 上層 階には展望台兼レストランが併設されており，かつて は市民の息いの場所となっていた。 しかし，紛争時に はJNAに真っ先に狙われた標的の一つとなり，著しい 損傷を受けた。現在は, 紛争時の攻撃で受けた 600 以 上もの弾痕がある状態で保存されている.

内部は現在立ち入り禁止となっており，外壁には紛 争を伝える小さなプレートが揭げられているだけで, 紛争についての記述や表象は比較的控えめである。し かしながら, 給水塔は高さが $50 \mathrm{~m}$ の巨大建築物で あり，砲撃跡を曝す痛ましい様子は，そこにありなが らすでに紛争の記憶を力強く語っており, 説明や演出 を加える必要がないのだろう。唯一の演出といえば, 屋上にはためくクロアチア国旗（図５には写っていな い)である.

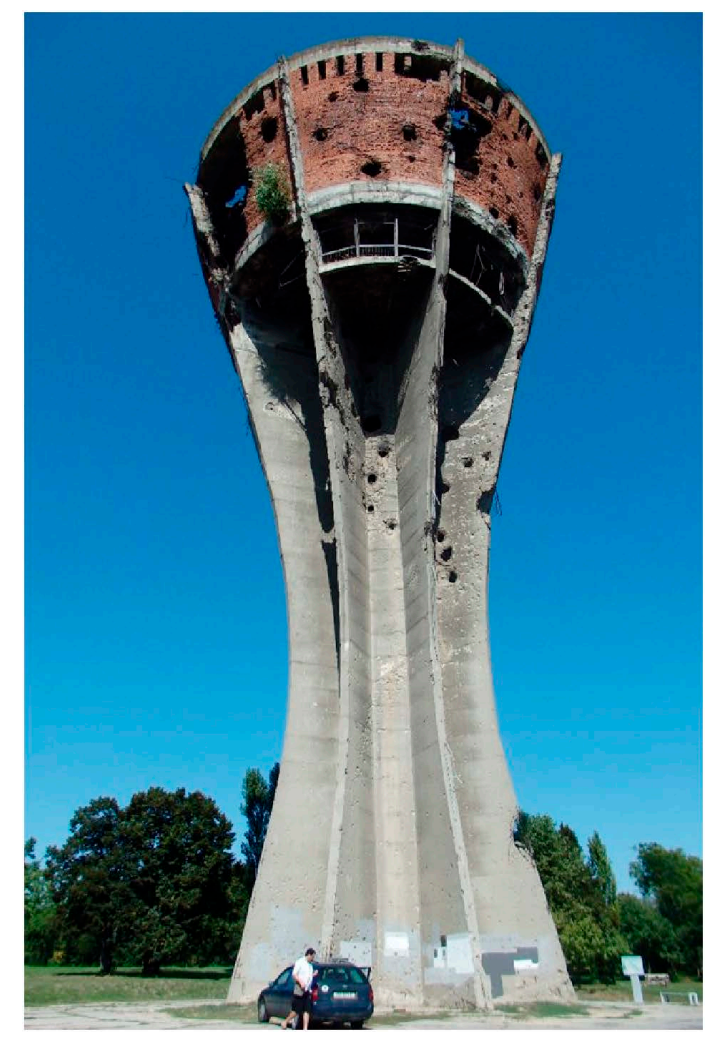

図 5 給水塔 (2016年 8 月 31 日撮影)

Fig. 5 Vukovar water tower
6）中央十字架

中央十字架は 1998 年 10 月にアドリア海の港町プー ラのクロアチア海軍によって贈呈された。戦争記憶を 象徴するものとしては，もっとも特徵的な記念碑であ る.

この十字架は，ヴコヴァル市街地のドナウ川とヴカ 川の合流地点に建っている. 高さ $9.5 \mathrm{~m}$, 重量 $40 \mathrm{t}$ の 重厚なつくりで, 図6からわかるように遠方からもそ の存在感が伝わってくる，十字架の横にはヴコヴァ ル・スリイェム郡の郡旗，クロアチア国旗， $\mathrm{EU}$ 旗が はためいている，傍らにはベンチがいくつか置かれ， 夜にはライトアップされる。普段から市民の散歩コー スに入るなど，人々が気軽に訪れる場所の一つとなっ ている.

この記念碑は, 台座部分と十字架部分がそれぞれ異 なった石材でっくられている．台座部分はクロアチア 西部にあるイストリア半島の都市パジンの石, 十字架 部分はブラチ島の石が使われている．ブラチ島はヴコ ヴァルからはるか離れたダルマティア地方にあり，良 質な石材が採れることで知られている。 また十字架部 分には, クロアチアの伝統的な組み紐文様プレテルが 施され，その下にはクロアチアの紋章と中世クロアチ アでのグレゴリー文字を用いた「誠実に死んだ者は， 永遠に生きる」という詩が記されている.

つまり，この十字架にはクロアチアの国土や歴史が 表象化されており，ここにはヴコヴァルの犠牲を記念 するだけでなく，クロアチア国民の総意が反映されて いると見ることができる。

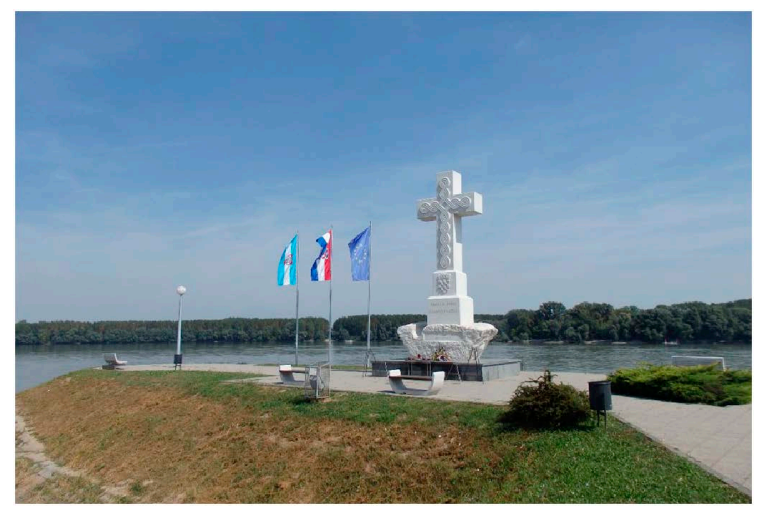

図6 中央十字架 (2016年9月 4 日撮影)

Fig. 6 Central cross in Vukovar 


\section{2. 記念碑の分析}

紛争の記憶を記念碑や行事などで表象し, 顕彰しよ うとする背景には, 必ず明確な目的や意思がある。 ク ロアチアのコメモレーションは，フットの四類型に当 てはめると, いずれもその場所が重要で記念行為の対 象とされる点で「聖別」ないしは「選別」に該当して おり，どれも似たような性格を有するように思われ る.しかし，それぞれのコメモレーションには，たと えば記念碑における碑文や，儀式における衣装のよう に，その意図が可視的に示されている場合が多く，そ れゆえに、これを手掛かりにしてコメモレーションの 表象内容を明らかにすることができると考えられる.

そこで，フットの景観分析の意義を踏まえつつ，先 の七つの記念碑が表象する内容について, ローカルと ナショナルという二つのレベルに分けて検討する.

1）ローカルレベルでの記憶の象徴

ルジャツの十字架, ボグダノヴツイの記念碑, ソ ティンの記念碑は, 犠牲者を追悼する目的だけでな く, 紛争時にその地域内で起きた事件を, その場所の 記憶として住民が共有するための記念碑として機能し ている.すなわち、これらは現地の住民が主体となっ て設置した記念碑であり，過去の記憶をその場所と結 びつけて継承することが求められている. そのため, 必ずしもそれが起こった場所ではなく，むしろ地域住 民の目に留まりやすい場所に設置されている.

ルジャツの十字架では, 犠牲者が出た現場ではなく, 犠牲者をまとめて一つの十字架に表象されている。こ のように犠牲者を 1 力所に集中させることで, 紛争の 記憶をローカルレベルで共有・継承させている。 ま た，ボグダノヴツィの記念碑では，ボグダノヴツィと いう小さな基礎自治体が, 時代を隔てながらも繰り返 しセルビアによる侵略の犠牲となったという記憶を一 つの記念碑にまとめることで共有している.ソティン の記念碑は, 設置主体が住民であること, そして立地 が地区の中心地であること, 記念碑の内容がソティン 地区の住民の記憶を共有させており，ローカルレベル の記憶を表象したものになっている.

2）ナショナルでの記憶の象徴

祖国戦争犠牲者のための記念墓地, 給水塔跡, 中央 十字架は, 都市や小規模な共同体レベルの枠を越えた クロアチア人共通の記憶が表象されている。ローカル
レベルの記念碑との違いは，具体的な事件を示すもの ではなく, 紛争全体の犠牲者の記憶を表象するもので あること, 表象内容が概して抽象的である点になる. また，いずれの記念碑も巨大で，ランドマークとして 目立つ記念碑である，以下，具体的に見てみよう。

祖国戦争犠牲者のための記念墓地は, 巨大な記念碑 や白い十字架の存在などによって，また毎年大規模な 式典の舞台となる，ヴコヴァルの犠牲を表象する巨大 な空間になっている，そのため，これらの記念碑はヴ コヴァルという都市レベルを超えた，クロアチア人に 共通した戦争記憶を象徴するものとなっている，つぎ に給水塔跡は, メモリアルセンターが「(給水塔跡は) この町の受難と抵抗, そして勝利, 新たな生命の象徵 である」と紹介するように，ヴコヴァルの戦い，そし てヴコヴァルという町自体のシンボルとして，その写 真や絵が国内各地で使用されている ${ }^{15)}$. 給水塔やオヴ チャラの虐殺現場周辺の土産店には, 給水塔を模した マグネットや石畧などが販売されている．給水塔は戦 争遺跡であるが, このように象徵化されることによっ て国内での知名度を高めており，クロアチア人の間で 共有される記憶の表象として十分に機能している。さ らに中央十字架は, 先に述べたように中世のクロアチ ア王国からの伝統の意匠, ダルマティア地方の特産品 の石材, クロアチアの紋章と, きわめて明確に「クロ アチア的」なものを表象した記念碑となっている.つ まり, この記念碑は「クロアチアの自由のために命を 落とした全ての人の名誉を記念」するものであり，記 憶はヴコヴァルに限定されていない. この点で, クロ アチア人で構成されたクロアチアという国家の記憶を 象徴しているといえよう。

ところで, これらが表象するナショナルな記憶が, セルビア系住民を含めたクロアチア国民ではなく，ク ロアチア人の記憶に限定されている点に注意したい. すなわち国民全体にとっての犠牲ではなく，クロアチ ア人にとっての犠牲が表象されている．いずれの記念 碑もセルビアによってもたらされた犠牲を表象してお り，七ルビア系住民にとって共有しにくい記憶なので ある。

3. 紛争を展示する記念館

ヴコヴァルにはメモリアルセンターを含め, 三つの 
紛争関連の記念館がある，以下，それぞれの特徵をま とめながら，ヴコヴァルにおける記念館の役割につい て検討する.

1) メモリアルセンター

メモリアルセンターは，2013年 5 月 3 日にヴコヴァ ル第204旅団の広大なバラック跡地に設置され, クロ アチア紛争に関する記念施設の運営, 研究, 教育活動 を行っている，紛争，特にヴコヴァルの戦いを紹介す る中心的な施設であり，毎年多くの来訪者を受け入れ ている.

展示の内容は, 当時のヴコヴァルの人々の抵抗に関 する記述や，当時使われた手作りの武器，JNAが所持 していた地図など多岐にわたる。また，屋外には戦場 が再現されており，当時使用されていたロケットラン チャーや戦車などの大型の兵器の展示のほかに, 小さ な川や塹壕も復元されている，墜落したJNA 軍の戦闘 機の一部も置かれている(図7)。このほか, 地下には JNAによる二つの強制収容所が再現されており, 地面 に小さな敷物を敷いた薄暗い空間に，むち打ちの姿勢 を強いられた人間が針金で表現されている（図 8).

施設職員によれば，このような展示は，国内各地か ら見学に訪れた学校生徒らにも戦争の経験を体感して もらうことを目指しているという.メモリアルセン ターが平和教育を行う教育機関であることは，「8年 生ヴコヴァル訪問プログラム」に見て取ることができ る。このプログラムは，祖国戦争教育を含めた現代史 を学習する小学校 8 年生 ${ }^{16)}$ がヴコヴァルを訪れるも

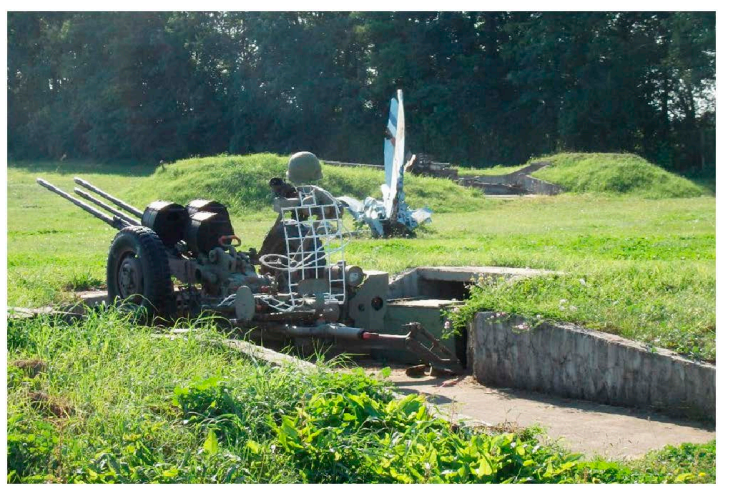

図7メモリアルセンター敷地内に再現された戦場, 奥にJNAの軍機の一部が見える (2016年 8 月 31 日撮影)

Fig. 7 Battlefield reproduction and JNA fighter aircraft in the Vukovar Memorial Centre
ので,メモリアルセンターをはじめとする施設や記念 的な場所を 2 日かけてクロアチア紛争とヴコヴァルの 戦いについて学び，そして平和の重要性を考える国家 的な学習プログラムである．プログラムの費用は, ク ロアチア退役軍人省から供出されている．2014/2015 年度にはパイロット版としてスラヴォニアの五つの郡 に住む約 7,000 人の 8 年生がプログラムに参加し，ヴ コヴァルの記念的な場所を訪れた。2015/2016年度か ら本格的にプロジェクトが行われており，これまでに クロアチア全土の 8 年生 42,791 人が訪問している ${ }^{17)}$.

このプログラムでの「平和教育」の最終目標は, 「生徒に共存, 理解, そして寛容を教えること」であ り，著名な政治家，スポーツ選手らによる自らの戦争 経験のレクチャーやワークショップ, クイズなどに よって生徒に主体的に平和な未来の構築を考えさせる プログラムとなっている.

以上のように，資料だけを見るだけでなく，見学者 が紛争当時を追体験できる展示の工夫がなされてお り，クロアチア紛争を体感してその記憶が共有できる 空間になっている.

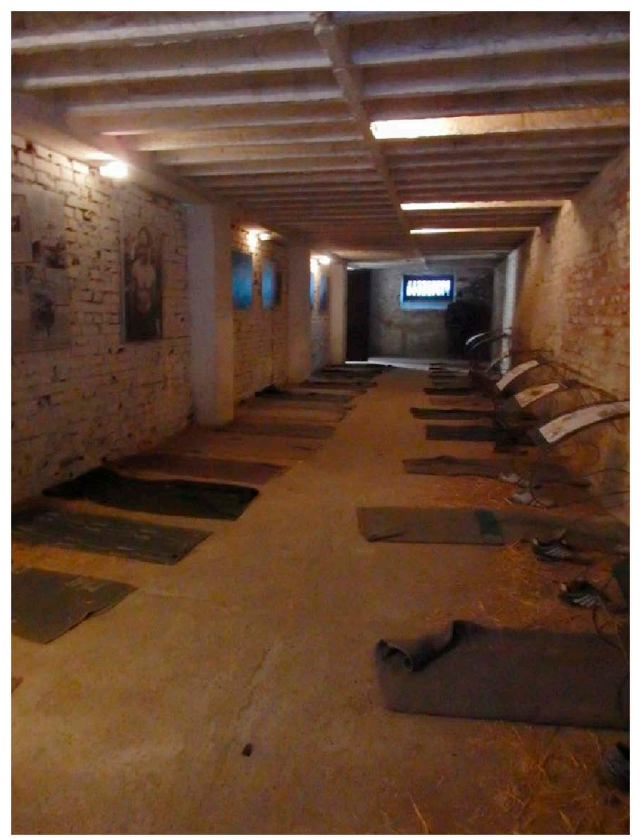

図 8 メモリアルセンターに再現された強制収容所の 様子

(2015年 11 月 17 日撮影)

Fig. 8 Concentration camp reproduction in the Vukovar Memorial centre 
2）クロアチア防衛軍記念館

この記念館は, 2011 年 9 月 24 日にヴコヴァル市長, 当時の首相, 退役軍人協会の代表者らによって, かつ て郵便局があった「トゥルピニスカ通り」に建てられ た（図9).

記念館の正面には，「勇敢な防衛軍によって破壊さ れた」JNA軍の戦車と「偉大なヴコヴァルの英雄」で あるブラゴ・ザドゥロという兵士の胸像が置かれてい る. 施設内は一つの大きな空間になっており，壁には 当時の紛争の状沉を映した映像が流れている。また， 中央には円筒形に区切られた空間があり，その壁には ヴコヴァル第204旅団の犠牲者の名前が赤く映し出さ れている. 円筒形の空間の足元にはJNA軍の戦車が 埋められており，当時使用された砲丸がこれを取り囲

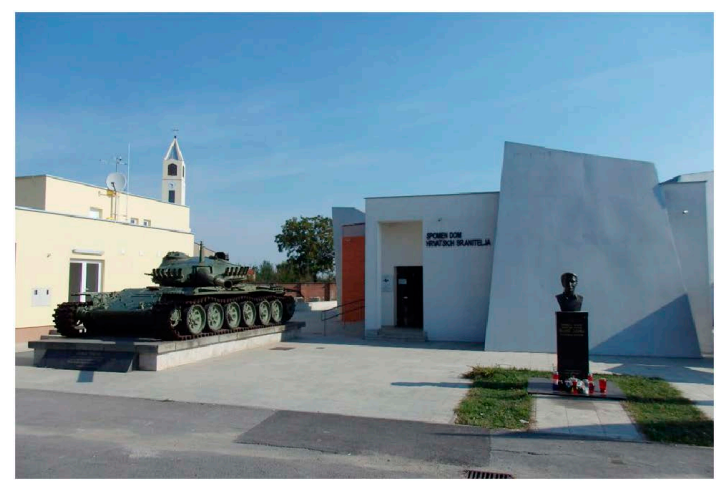

図9 クロアチア防衛軍記念館 (2016年9月 4 日撮影)

Fig. 9 Croatian defenders' Memorial Home, located on Trpinjska Street, Vukovar

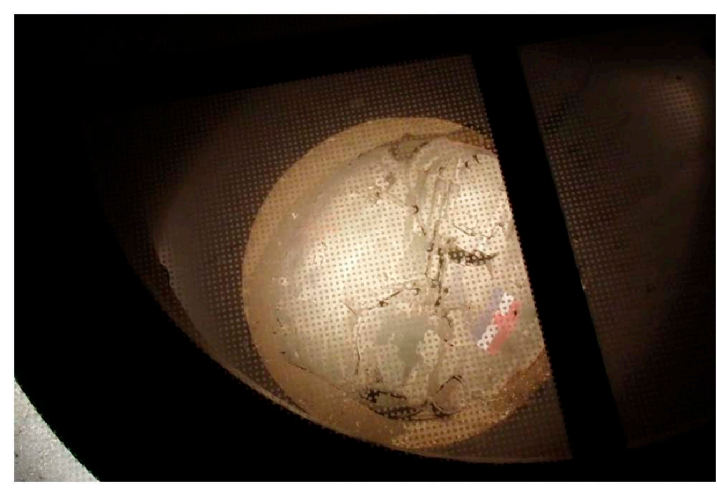

図10 クロアチア防衛軍記念館に埋められたJNAの 戦車

(2016年9月 4 日撮影)

Fig. 10 JNA tank in the Croatian Defenders' Memorial Home
むデザインになっている(図 10)。ここでは, ヴコ ヴァルは防衛軍の犠牲の上に成り立っているという強 いメッセージを受け取ることができる。この記念館は クロアチア防衛軍の犠牲を表象し，さらに戦争記憶の 一つとして彼らの犠牲を象徴的なものにしている.

3）オヴチャラの虐殺記念館

IIで述べたように，オヴチャラの虐殺はクロアチア 紛争において最も大規模なものであり，祖国戦争に関 する教育でも必ず学習される。

現在, この記念館はオヴチャラの集団墓地の近くに あり，オヴチャラの虐殺が起きた 15 年後の 2006 年 11 月20日に，「セルビアのヴコヴァル強制収容所捕虜協 会」によって開設された，入口には薬きょうが埋め込 まれた床が広がり, 虐殺現場となった農場の扉がその まま使用されている，中に入ると，壁一面に犠牲者の 写真や名前が書かれ，その足元には彼らの遺品が展示 されている，集団墓地から発掘された遺品は，身分証 や時計，ロザリオなどさまざまである。この施設の中 央にも，うずまき状の小さな空間（ここは膝より低 い）があり，赤いライトで表示された犠牲者の名前が 円を描きながらそのうずまきの中心部に吸収される演 出がなされている.

この記念館はヴコヴァルで訪れるべき場所の一つと なっており，集団墓地とともに当時の虐殺について考 えさせるようになっている，きわめて知名度の高い虐 殺を展示する記念館であり，ヴコヴァル市民に限ら ず，クロアチア人全体にアピールする場となってい る。虐殺の悲劇を視覚的に表現することによって，虐 殺の記憶を共有させ，それを強固にする機能も果たし ている.

4）ヴコヴァル市立病院

ヴコヴァル市立病院（以下，市立病院）は，紛争当 時負傷した兵士や市民を民族の分け隔てなく受け入れ， ヴコヴァルがJNAによって包囲され攻撃にさらされた 際も，地下で治療を続けていた。当時の市立病院のス タッフらの懸命な㗢きぶりや，のちにオヴチャラ虐殺 に巻き込まれた彼らの悲劇的な死を踏まえると，ヴコ ヴァルの戦いはこの病院抜きに語ることができない.

現在, 市立病院は医療機関として機能しているが, その地下には戦時病院の様子を伝える展示がされてい る。地下の展示フロアに入るとまず，戦時中のヴコ 
ヴァルや病院の様子が記録されたDVDが上映される. そして，壁に犠牲者の名前や紛争の時系列が書かれた 廊下の先には, いくつかの部屋にわたって戦時中の病 院の様子が当時の器機や人形で再現されている (図 11 ). 3段ベッドが所狭しと置かれた部屋を抜けると, 最後 に鏡張りの部屋にたどりつく，その部屋の中央には電 燈のロウソクだけが置かれ，犠牲となった人々を追悼 する空間となっている.

市立病院は，11月に開催される記念式典の行事にお いても重要な場所の一つなっている。11月18日のメイ ンイベントの前夜には, 市立病院中庭の記念碑の前で ロウソクが点灯され，その様子はテレビ中継される. そして18日には, 警察音楽隊による合唱の後, ここ を起点に郊外の記念墓地までの行進が行われる ${ }^{18)}$.

このように，市立病院はヴコヴァルの戦いを語る上 できわめて重要な場所であり, 当時の展示や記念式典 の中心地となることから, 戦争記憶を留める重要な場 所であることは明らかである。 それは，ヴコヴァル市 内のローカルレベルだけでなく，クロアチア国内のク ロアチア人全体に共有される記憶であり，市立病院が ナショナルレベルで共有される戦争記憶の象徵となっ ている.

\section{4. 犠牲者追悼記念式典}

ヴコヴァルでは，この町が陥落した 11 月 18 日に， 毎年大規模な記念式典が行われる。記念式典には, 「ヴコヴァル一特別な崇敬の場所」というタイトルが

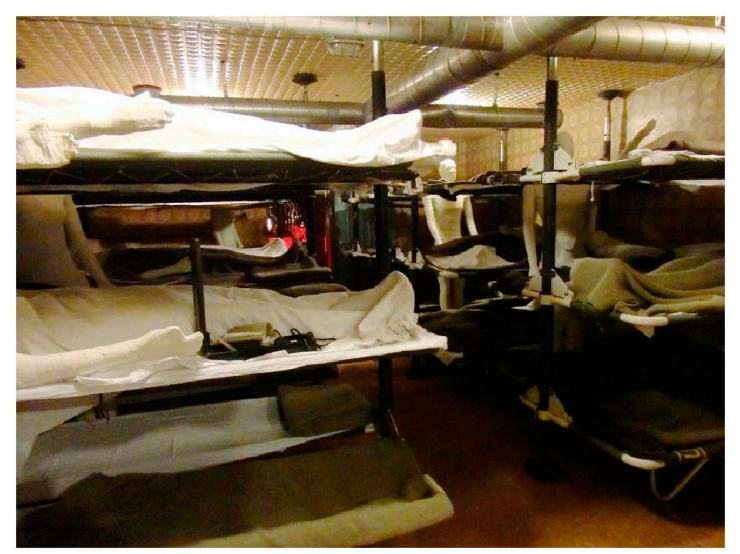

図 11 ヴコヴァル市立病院内にある紛争時の再現展示 (2015年 11 月 17 日撮影)

Fig. 11 Conflict evhibit in Vukovar City Hospital
つけられている。2006年から始められたこの記念式典 は，ヴコヴァル市が主催し，ヴコヴァル・スリイェム 郡とクロアチア共和国がサポートをしている。11月 18日を中心に，前後3日間ほど関連の行事もあわせて 行われる。ここでは，2015年11月18日の記念式典に 参加した際に確認したことをもとにまとめる.

式典は午前 8 時から終日，連続して行われる，当日 は国内各地からテレビ局が集まり，記念式典の様子が SNS やニュースなどでリアルタイムに伝えられる。 中 でも注目されるのが「記憶の行進」である。政府要人 から一般市民まで数万の人々がヴコヴァル市立病院の 中庭に集まり，そこから郊外にある記念墓地までの約 $5 \mathrm{~km}$ ，給水塔跡や死者の名前が書かれた垂れ幕を 目にしながら歩くものである（図 12）.

11月 18 日はクロアチアの祝日ではないが, この日は 国内各地から多くの人々がヴコヴァルに集結する ${ }^{19)}$. 報道によると，ヴコヴァルの戦いから 25 年経った 2016 年は 10 万人， 2019 年は 6 万 5 千人の人々が訪れたとい う ${ }^{20)}$.

午後 6 時には「私の町でもヴコヴァルは光っている」 というイベントが開始される。これは国内の多くの都 市にある「ヴコヴァル通り」(ない場合はメイン通り) で同時にロウソク点灯を行い, ヴコヴァルの戦いで犠 牲になった死者を追悼するものである. ヴコヴァルの 名前のついた通り ${ }^{21)}$ で同じ時間に同じ行為をするこ とにより, ヴコヴァルから離れた場所でも人々は追悼 の一体感をもつことになる.

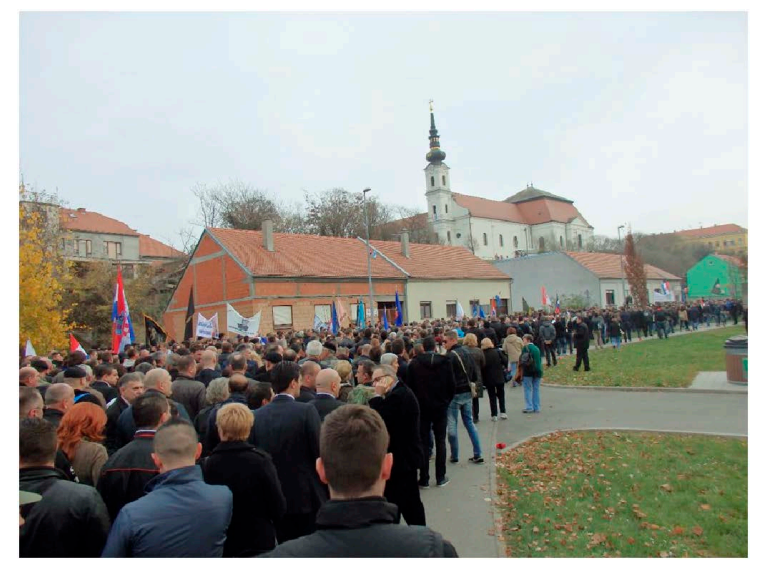

図 12 記憶の行進 (2015年11月 18 日撮影)

Fig. 12 Memorial March in Vukovar 


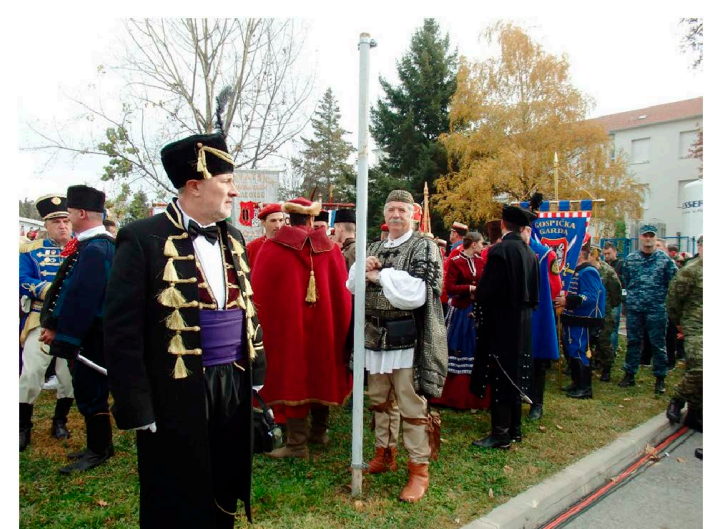

図 13 歴史的な衣装を着た記念式典参加者 (2015年11月 18 日撮影)

Fig. 13 Participants in a ceremony wearing traditional Croatian dress

記念式典には, クロアチア大統領を筆頭に政府要人 や，ヴコヴァルの姉妹都市の関係者が参加する．また 記念墓地での行事には聖職者や軍人などの姿も見られ る。そのほか, 国内各地の伝統的な戦士の衣装を着た 人々も見られる（図13）。これらの衣装はヴコヴァル の戦いとは関係なく, クロアチアの歴史や伝統文化を アピールするものであり，ここにはクロアチア人意識 を高揚させようとする意図が透けて見える ${ }^{22)}$ ：このよ うに，この式典は国内各地からの参加者を呼ぶ国家的 行事になっている.

5. セルビア系住民のコメモレーション

ここでは，ヴコヴァルのセルビア系住民にとっての 紛争に関するコメモレーションを整理する.

ヴコヴァルの戦いでは，多くのセルビア人で構成さ れたJNAによるクロアチア人の殺害や強制労働など がクローズアップされがちである。しかし，紛争が始 まると，JNAによるヴコヴァル包囲以前にクロアチア 人とセルビア系住民の関係は急激に悪化し，クロアチ ア人によってセルビア系住民が殺害されるケースも多 く見られた。紛争中に殺害されたセルビア系住民は 150 人にのぼったというう.

現在，セルビア系住民によるコメモレーションはわ ずかながら見られるが，それらはクロアチア人のコメ モレーションと大きく異なり，小規模であったり，場 合によっては事件についての表象もされていないこと がある。ここでは，まずセルビア系マイノリティのコ

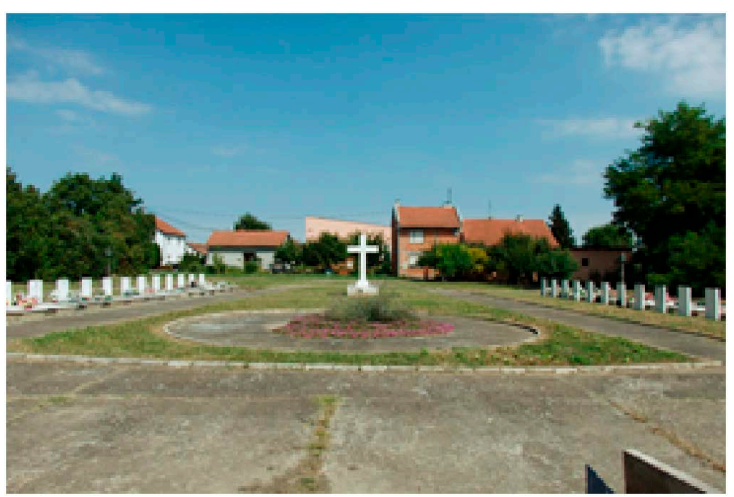

図 14 セルビア系住民犠牲者の記念広場 (2016年9月 1 日撮影)

Fig. 14 Memorial site for Serbian victims of the conflict

メモレーションを整理し，つぎになぜそのような規模 にとどまるのかを，セルビア系住民のための記念碑と 記念行事に着目して検討する。

1）セルビア系住民犠牲者の記念広場

市街地にある聖ニコライ教会から数百 $\mathrm{m}$ 南下する と別のセルビア正教会がある（現地のセルビア系住民 は主にこの教会に通う)，その正教会の脇にある，直 接道路には面していない広場に記念碑は設置されてい る（図14）。現地のセルビア系住民への聞取りによる と，この記念碑は1994年頃，ユーゴスラヴィア支配 下で建設されたという。一帯はセルビア系住民が多い 地区であり，広場の中央に置かれた十字架を中心にし て，左右にそれぞれ13名のセルビア系住民の犠牲者 を悼んだ墓石のような碑が建てられている，墓のよう に見えるが, 遺体は全てセルビア本国に運ばれている。 石碑には個人の顔写真と名前がキリル文字で書かれて おり, 現地調査時には全ての石碑の前に新しい花束が 置かれていた.

2）ドナウ川での花流し

毎年 6 月 28 日 $^{24)}$ にセルビア系住民の遺族がヴコ ヴァル市内のドナウ川河畔に集まり，犠牲者を追悼す るために花を流す。紛争中, クロアチア人によって殺 害されたセルビア系住民の遺体は，どこかに埋められ るかドナウ川に流されるなどされたからである，花を 流す場所には特に目印となるものはなく（図 15）, こ の行事は遺族らが静かに花を流して終わる.

3）不可視化される犠牲

紛争時のヴコヴァルでは, クロアチア人だけでなく 


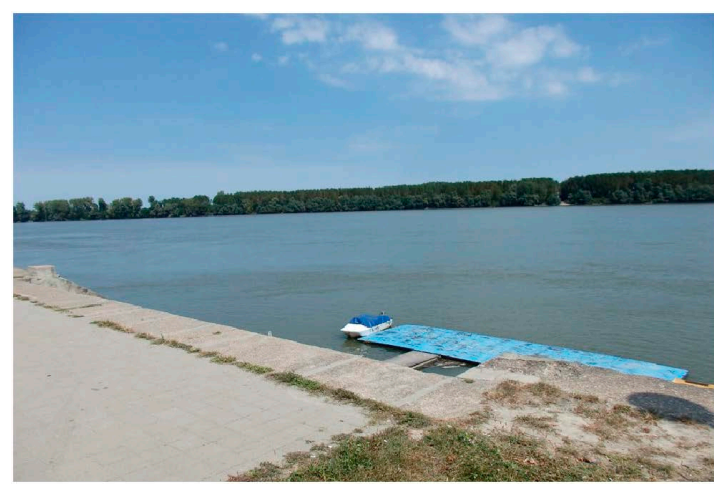

図 15 花流しが行われるドナウ川河岸 (2016年9月 1 日撮影)

Fig. 15 Serbian commemoration site on the bakns of the Danube River

セルビア系住民も犠牲になったが, 彼らの多くは今な お口をつぐまねばならない状況にある。セルビア系住 民が自分たちの犠牲について話すことは，クロアチア 人の民族感情を逆なですることにつながりかねない. セルビア系住民が自らの犠牲を主張しないことは，マ イノリティである彼らがクロアチアで（たとえ表面上 であっても）平穏に生活する工夫であり，そのために 現在のヴコヴァルではセルビア系住民の犠牲が見えな い状況となっている.

セルビア系住民の犠牲者の数は，今な㧍把握されて 扮らず，また行方不明の者もいる。この地域ではクロ アチア人とセルビア系住民の衝突が頻発し, 特に紛争 前にはセルビア系住民（もしくはセルビア系住民を配 偶者にもつクロアチア人）は，クロアチア人に理由も なく殺害されたり，連れ去られたりした。このような クロアチア人による紛争時の犯罪は, 紛争後も焒めら れておらず，七ルビア系住民遺族が保険などを申請し ても認可されないなど，一方的に不利な状況にあると いう ${ }^{25)}$.

クロアチア人によるセルビア系住民の殺害は当時突 発的に生じていたが，たとえばボロヴォ地区の事件が 挙げられる. ボロヴォ地区はヴコヴァル市北部に位置 し，ユーゴスラヴィア時代から有名な靴・ゴム工場で は多くの工場労働者が従事していた。1991年11月ボ ロヴォの工場にあった核シェルターに市民が集まって いたところ，数人のクロアチア人がセルビア系住民だ けを連れ出し，ボロヴオ地区の公園に集めて殺害した （図16）、殺されたセルビア系住民は 15 人ほどである

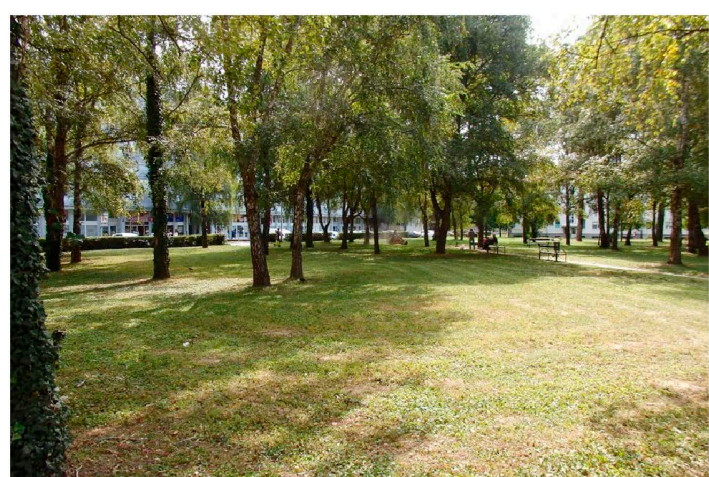

図 16 ボロヴオ地区のセルビア系住民殺害現場 (2016年9月 1 日撮影)

Fig. 16 Site of a Serbian massacre in Borovo district, Vukovar

が，殺害の詳しい理由や背景はわかっていない．

セルビア系住民殺害の現場となった公園も維持され ているが, ここが紛争中に殺人の事件現場となったこ と，十数人のセルビア系住民が殺害されたことは一切 示されていない.

紛争中にこのような事件が発生し，自分の親族や友 人が犠牲になっても，彼らはセルビア系住民というナ ショナル・マイノリティであり, 犠牲を声に出すこと は現在に至るまでほとんどなされていない。クロアチ ア人とセルビア系住民の微妙で繊細な関係が， セルビ ア系住民犠牲者の主張を内に閉じ込め, 不可視化させ てしまっている.

6. 小括：戦争記憶とコメモレーションの関係

1）クロアチア人の記憶とコメモレーション

クロアチア人の記憶の表象については，すでにロー カルレベルとナショナルレベルでそれぞれ整理した. ここでは，そうした記憶の表象とコメモレーションの 関係についてみてみよう。

まず，ローカルレベルでの記憶の表象は，実際に起 こったことを直接的に，もしくは家族や知人を通して 間接的に体験している地域の人々を対象にして，その 記憶の維持・継承を促すものになっている，そのため に，JNA，つまりセルビア系勢力の進攻によって地区 の人々が犠牲になったことがじかに理解できるような 形態をもち，ときにセルビア系住民に対する梁い憎悪 感情にまで発展するような景観を保持している.

たとえばボグダノヴッィでは，歴史の歪曲化とも思 
えるような独特の解釈によって地区の住民に対して蛮 行を行うセルビア人の歴史的な連続性を強調している. また，興味深い特徵として，地区の人々と死者の距離 が近く，かつ死者が英雄化されていることである。す なわち，家族や身近な住民の死は遺族らにとって深い 喪失感を与えるため, 死者を顕彰してその死が無駄で はなかったという言説のうちに垜失感を埋めるのであ る. 実際, この象徵型で表象される地区の犠牲者は自 ら命を捧げた兵士というより, 多くは不条理に殺害さ れた一般市民である。そして，ときに死者は生きてい る私たちに語りかける形で, 自分たちの犠牲は意義あ る死であったと折り合いをつけているのである。

つぎに, ナショナルなレベルでの記憶の表象につい て検討する．すでに指摘したように，このレベルでの 記憶として, ヴコヴァルの戦いにおける戦争の記憶が クロアチアの国民的記憶の一つとして位置づけられな がら，実際にはセルビア系住民を含まないクロアチア 人が対象になっている.

ここに該当するコメモレーションに共通するのは, その表象が抽象的であり, あるいはクロアチアの伝統 的な衣装を利用している点である。 ノラ（2000: 35） も指摘するように，ここでは必ずしも立地場所は重要 ではなく，コメモレーション自体が示す顕彰にこそ意 味がある ${ }^{26)}$. ヴコヴァルの戦いの直接的な記憶をもた ない外部者によって設置され，その抽象的な形態か ら，見るものにさまざまな解釈の余地を与える。

938本の白い十字架を前にして, 自分とは直接関係 のないクロアチア人に思いを馳せることは，エスニッ ク・クロアチア人という集団の記憶を想像し，共同体 としての意識を創造することにつながる，また，記念 施設において，JNAの進攻による被害やそれによる犠 牲者の示すだけにとどまらず，JNAの武器や戦車を踏 み台として使用する演出は, 見学に訪れたクロアチア 人（この場合クロアチア・エスニックだけに限らな い）の生徒は戦争記憶を追体験させ，若いクロアチア 人にもその記憶が継承されていくのである.

ヴコヴァルにおける「記憶の行進」も同様の意味が あると考えられる。追悼儀式で行われる行進には, 時 空を超えた事実の再確認と追体験を重視する目的があ り，そこにはその戦争記憶を記憶し続ける意味がある とする指摘（関沢2010）を待つまでもなく, 紛争後
に国家やヴコヴァル外部から積極的に行われたさまざ まなコメモレーションによって, ヴコヴァルはクロア チア人の戦争に関する国民的記憶を形成する空間と なったのである、いずれにおいても，そこに国内に暮 らすセルビア系住民の入る余地はない.

2）セルビア系住民の記憶とコメモレーション

クロアチア人固有の歴史や文化を強調するクロアチ ア人のコメモレーションと比較すると, セルビア系住 民のコメモレーションは彼らが多数を占める場所でな ければ，ほとんど目立たない。そこにはいくつかの背 景がある。

一つは，セルビア人がクロアチアをかつて攻撃した 敵国であるという事実である。この事実によって，一 部のクロアチア人はセルビア系住民に対していまだ根 深い憎悪感情を抱いており，またクロアチアの愛国主 義者は敵対的な態度をとる，ときには記念式典の 11 月 18 日にヴコヴァルに多くの市民が集まった際に， 退役軍人ら一部のクロアチア人がヴコヴァルにおける キリル文字使用を容認できないと大々的に主張する (図 17)。キリル文字はセルビア人と同義であり，こ のようなクロアチア人の動きはクロアチアに住むセル ビア系住民を排斥する運動ともとらえられるのである (図 18) ${ }^{27)}$.

セルビア系住民がクロアチア人社会におけるマイノ リティであることも, 彼らのコメモレーションをめぐ る活動を抑え込んでいる. 彼らは数において, クロア チア人よりも圧倒的に少なく，それゆえにクロアチア

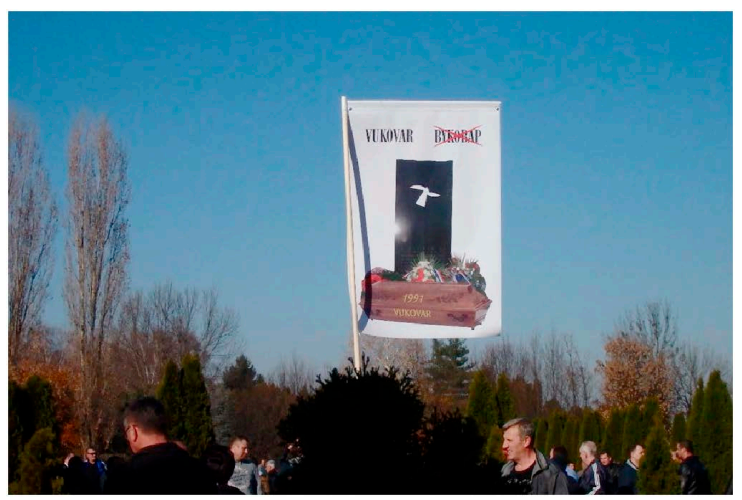

図 17 記念式典で見られたセルビア語排斥の旗 (2015年 11 月 18 日撮影)

Fig. 17 Flag marking withdrawal of recognition of Serbian as an official national language 


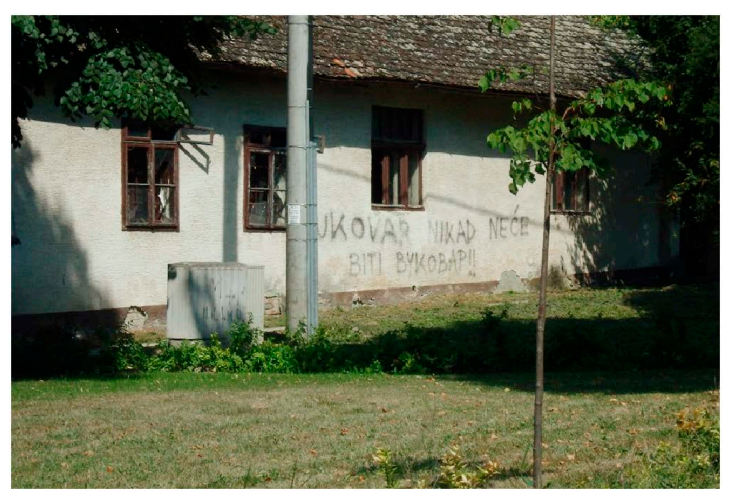

図 18 ヴコヴァル市内の落書き。「ヴコヴァルVUKOVARは決して（キリル文字の）BУKOBAPに はならない! !」

(2016年9月 4 日撮影)

Fig. 18 Graffiti in Vukovar

人社会においてセルビア系住民たちの声は届きにくく， かつ声をあげようものならクロアチア人社会からの追 放や身の危険を感じることにつながるからである ${ }^{28)}$.

このような背景によって，セルビア系住民は犠牲者 追悼の意思を内在化させている. 彼らの犠牲者を追悼 する動きはあったとしても，その規模は小さく，場合 によっては殺害事件の現場を顕彰することもためらう のである. クロアチアのセルビア系政治家や，七ルビ ア系住民向けの新聞は彼らの追悼の必要性を訴えては いるが, その声は大きくない. セルビア系住民の戦争 記憶は, 彼らの小さなコミュニティの中でのみ, 小規 模に継承されているにすぎない.

\section{IV ナショナル・アイデンティティの強化・継承}

1. 国民統合のためのクロアチア・ナショナリズム 多くの研究者たちが指摘するように，国民国家に よって一側面のみ選択された戦争記憶は, 顕彰される ことによって国民にナショナル・アイデンティティを 想像させ，国民意識を統合する役割を果たす ${ }^{29)}$. クロ アチアのヴコヴァルの戦いにおける戦争記憶の表象を 分析すると, 表象の対象はクロアチア人に絞られてい ることが明らかになった，つまり，国家によって選択 され顕彰される戦争記憶は, セルビア系住民のような マイノリティを含むクロアチア国民よりも，むしろク ロアチア人のためのものになっている. クロアチア人 は総人口の圧倒的多数を占めるだけでなく, 戦争記憶
の表象の面から見ても, クロアチアはクロアチア人の 国家，すなわち自民族中心の国民国家であることがわ かる.

ナショナル・アイデンティティを強化し，次世代へ 継承するような積極的な動きが現在のクロアチアで起 きている理由を検討する上で，こうしたクロアチア人 中心の国家がなぜ形成されたのかを考える必要があ る.ここではクロアチアの歴史から生まれたクロアチ ア独自の政治的動きがあることをまとめておく．

まず，国家建設を強く求めてきたクロアチアの歴史 を挙げることができる，クロアチアは，他国による国 土分割を繰り返し ${ }^{30)}$ ，多民族国家に内包される歴史を 経てきた。このような背景から，中世クロアチア王国 の版図並みの国土回復に対する強いこだわりを生んだ. このこだわりは，クロアチアでは多民族国家ユーゴス ラヴィアからの自治獲得や分離独立が何度も図られて いたことや，第二次世界大戦中のクロアチア独立国 ${ }^{31}$ の時代に，一時的ではあれクロアチアの歴史的版図が 回復されたことなどから見て取れる．戦後のユーゴス ラヴィア時代にクロアチアは再び領土を分割されたこ とから ${ }^{32)}$, 領土と主権の回復は悲願であった.

エスニック・クロアチア人の分布が現在のセルビア 北部のヴオイヴォデイナ地方やオーストリア東部のブ ルゲンラント州にまで及んでいることも，国土保全に 対する関心を高めることになった，第一次世界大戦後, 東ヨーロッパでは民族自決による主権国家を成立させ ることが可能になったが，クロアチアは当時の国際情 勢を踏まえてセルビアなどの周辺諸国と連携をとり， ユーゴスラヴィアを成立させた．クロアチア人中心の国 家が建設されなかったことを不服とする声が高まり ${ }^{33)}$, クロアチア人は自らのエスニックの独自性を強調する とともに，国土の確保に強い関心をもつようになって いった。

つぎに, クロアチアの脱バルカン・親ヨーロッパ志 向が挙げられる. クロアチアは地理的にも文化的にも 自らをヨーロッパの一国家ととらえており，また「バ ルカン」という語が後進的で否定的なイメージをもつ ことから，バルカン諸国とみなされることに嫌悪感を 抱いてきた（定形 2006，コレン 2008）。こうした意識 から, クロアチアは脱バルカンや脱ユーゴスラヴィア を強く求め，多民族国家からの独立に向かうことに 
なった ${ }^{34)}$

ローマカトリックの信仰やラテン文字の使用，ドイ ッなど西ヨーロッパ諸国との積極的な人的交流や貿易, アドリア海沿岸でのインバウンドッーリズムに向けた 観光開発などは, 明らかに西ヨーロッパとの連携を強 めてきた。 そして2013年のEU加盟は，セルビア以南 の旧ユーゴスラヴィア諸国と袂を分かち，ヨーロッパ の一員になることを確定させる機会となった．

以来，クロアチアは独立のために多大な犠牲を払っ た国であることを積極的にアピールしている。ヴコ ヴァルの被害は国際世論の同情を集め，独立の正当性 を確固たるものにした，しかも，ヴコヴァルはセルビ ア人による攻撃の犠牲になったとともに，戦略上の犠 牲も強いられた。そのためにヴコヴァルの犠牲を栄誉 あるものとして国を挙げて称え，クロアチア国家建設 のために追悼することで, 紛争の意義を強調すること になった。

さらに，こうしたクロアチアの歴史的経緯がクロア チアのナショナリズムを活発化させ，クロアチア人に よる国民国家の成立に邁進することになった。クロア チア国民の統合に際して, 戦争の記憶は重要な手段で あり，国家はそれを最大限に利用している，加害者で あるセルビア人が登場する紛争の物語は, クロアチア 人の連帯意識を強め, クロアチア人からなる国民国家 の成立を確固たるものにしつつある.クロアチア人主 体の国民国家クロアチアは，戦争記憶を毎年想起させ ることでクロアチアのナショナル・アイデンティティ を強め, 紛争を直接経験していない次の世代にその意 識を継承させようとしている.

一方，国内の地域レベルでは，国家レベルとは異な るアイデンティティの強化・継承がなされている，国 家レベルでは，紛争の記憶を直接経験したことのない 国民にも想像・共有させ，国民の一人であるという想 像力を養わせた。 これに対して紛争の起こった地域レ ベルでは, 紛争は想像されるものではなく経験であり, そこでの戦争記憶は，犠牲となった家族や知人を追悼 し，英雄視することによって衰失の穴をふさぐ機能を もっている，そしてクロアチア人の犠牲への悲しぬは, セルビア人が敵であった事実を前にして, クロアチア 人同士で被害者意識を共有することによって慰められ る.ここでは感情的な戦争記憶が, その地域のクロア
チア・エスニックの記憶として留められる。これに よってクロアチア人のナショナル・アイデンティティ は地域で共有され, 継承されていくのである.

以上をまとめると, クロアチアのセルビア系住民 は，国家レベルと地域のレベル両面において，それぞ れ侵略者・加害者としてみなされることにより，ク口 アチア人の連帯感を高める結果になっている.

\section{2. クロアチアのマイノリティ保護要請}

歴史的にヨーロッパを志向してきたクロアチアは, 独立の後にEC（現EU）加盟を目指し，2013年に実現 させた，そこには，自由な資本主義社会への参入を求 めるクロアチアと，経済規模の拡大のために拡大を続 けるEUの思惑の一致がある.

ただし，EUは多民族共生を理想に掲げており，EU 加盟には国内のマイノリティ保護政策を実施が前提と なる。そこで，EUが打ち出す条件には法的権限がな いものの，加盟を目指すクロアチアはマイノリティ集 団に対する政策を新たに打ち出すことになる.

そもそも独立紛争以来，クロアチアではトゥジマン 大統領によるクロアチア人優先の強引な政策が続けら れてきた。しかし，それは次第にクロアチアの国際的 な孤立を招いた，民族主義が前面に出す政権下では， EU加盟に必要なマイノリテイ保護に関する法整備もお ざなりになっていた．1999年のトゥジマン大統領の 死後，政権が左派連合へ移行したことをきっかけに， 2000 年以降クロアチアはEUへアピールするために大 きく舵を切った，その一つが，クロアチアにおけるマ イノリティ保護政策の整備である.

マイノリテイ保護に関する重要な法律は主に3 点あ る. 1点目は「クロアチア共和国に㧍けるナショナル . マイノリティの言語と文字の使用に関する法律」であ る。これにより, 各自治体でマイノリティが総人口の 3割以上を占める場合，マイノリティの使用する言語 や文字を公共の場で使用することが義務づけられ，公 的機関ではクロアチア語と共に二言語表記されること となった。また，マイノリティのための新聞が各地で 発行されるようになり，マイノリティによる活動の後 押しが図られた ${ }^{35)}$. 2点目は「ナショナル・マイノリ ティの言語と文字による教育に関する法律」の制定で あり,これによって学校でマイノリティの使用する言 
語や文字が尊重され，マイノリティ向けの特別授業が 行われる配慮を施した. 3 点目は「国会議員選挙法 十七条」によってクロアチア議会での各マイノリティ 代表の選出が義務づけられることになった。たとえば セルビア人の場合, 代表 1 名の枠が設けられており, 現在はセルビア系マイノリティの代表である独立民主 セルビア人党（SDSS）が3名の議員を議会に送って いる.

このほか法整備とは別に, 1997年に設立されたクロ アチアのセルビア系住民を統括する組織として「セル ビア民族会議」がクロアチアのほぼすべての郡に支部 が置かれている，セルビア民族会議を中心に，さまざ まなセルビア系団体がクロアチア政府と協調して， 「セルビア人の人権擁護とアイデンティティの構築と 二本柱として多様な文化活動を」行っている（百瀬 2017: 217).

また, クロアチア紛争によって国外へ逃れたセルビ ア系難民の帰還事業も，2000年以降なされている.

こうした政府の動きにより，マイノリティにとって 理想的な法律が整備された.この動きは EUも高く評 価しており，「クロアチア政府が域内のナショナル・ マイノリティの権利向上を促進すること」が期待され (百瀬 2014: 175, 176)，そのことがクロアチアのEU加 盟へとつながった。

3. ナショナル・アイデンティテイの強化・継承が 生む問題

1）ヴコヴァルにおけるマイノリティ保護政策の現 実

マイノリティ保護政策が制定された一方で, 紛争後, 国家統合のためにナショナル・アイデンティティの強 化を続けてきたクロアチアでは, すでにいくつもの問 題が生じており, 一部のナショナル・マイノリティの 生活に影響が出ている.

クロアチアにはさまざまなナショナル・マイノリティ がいる.しかし，たとえばイストリア半島のイタリア 系住民やスラヴォニアのハンガリー系住民は, クロア チア人の間に目立った問題を抱えていない. しかし， セルビア系住民とクロアチア人に関していえば, 紛争 によって両者の関係は亀裂が生じたままであり，ヴコ ヴァルではマイノリティ保護の理想と現実の乘離が鮮
明になっている。このような地域の問題が解決されな い限り, クロアチアは完全にマイノリティの権利を保 護できているとはいいがたい。セルビア系住民マイノ リティがクロアチア社会で抱える問題を, ヴコヴァル を例にして考察する.

ヴコヴァルでは，1998年に市内にセルビア領事館 ${ }^{36)}$ が置かれ，2019年現在では23名で構成されるヴコヴァ ル市議会にSDSSに所属するセルビア系の議員が3名 加わっている．一見セルビア系住民マイノリティの権 利が十分保護されているような体制に見えるが，いま だ十分とは言えない現状が見られる。まず挙げられる のは，図19に見られるような一部のクロアチア人によ るキリル文字への反発である。セルビア系住民が3割 以上居住する地域では，彼らの言語が公的に使用され ることが認められている。しかし，ヴコヴァルでは現 在もそれは十分に実現されていない.このことに対し て，現地のセルビア系住民はマイノリティに対する権 利が保障されていないと感じている，そのようなセル ビア系住民の不満を横目に，2015年にはヴコヴァル 市議会で公的表示からキリル文字を削除することを決 定した。これはセルビア系住民が歓迎されていないこ とを示す明確なメッセージであり，彼らはクロアチア 人に同化するか，もしくは立ち去るかの二択しかない という強烈なものであった ${ }^{37)}$. ヴコヴァル市議会のこ のような決定に対してEUは懸念を示したが，マイノ リティ保護違反を処罰する法的権限をもっていないこ ともあり，この決定に対して特別な措置は現在行われ ていなかった ${ }^{38)}$ 。しかし，2019年7月，クロアチア憲

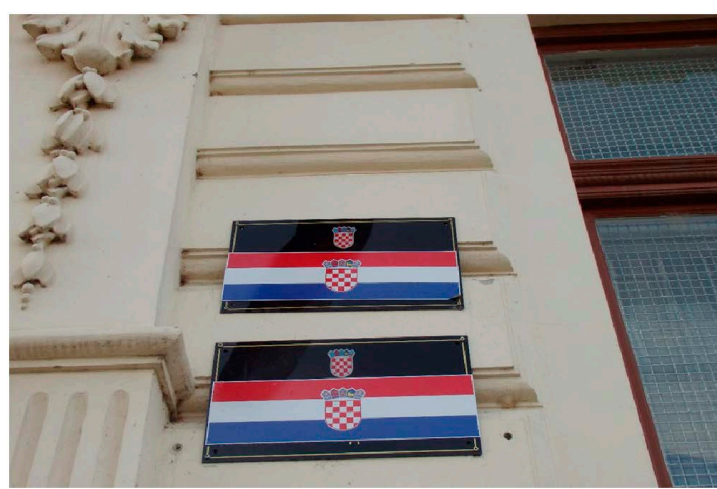

図 19 シールで隠された二言語表記のプレート (2015年 11 月 20 日撮影)

Fig. 19 Concealed plates with bilingual inscriptions and seals 
法裁判所は 2015 年のヴコヴァル市の決定に反対して いた一部の主張を受け入れ，ヴコヴァルにおいて二か 国語表記としてのキリル文字を使用することを決定し た.このような憲法裁判所の決定が出たにもかかわら ず，保守系政党がヴコヴァル市政を握る現在，二か国 語表記としてのキリル文字使用に関する市議会決議で は混乱が生じ, 市としての決定はいまだ持ち越されて いる ${ }^{39)}$ 。キリル文字が一部の人々にとって憎しみの対 象であり続けている現在，ヴコヴァル市がどのような 動きに出るのか, 今後の対応が待たれる.

また，ヴコヴァルでは，幼稚園と小学校でクロアチ ア人とセルビア系住民の生徒の教室が完全に分けられ ている。これは先に挙げたマイノリティ保護を目的と した教育に関する法を反映したものである。しかし， 実際には生徒が民族により二分されており，双方の交 流が学校内でほとんどないことからセルビア系住民の 間で懸念の声があがっている，現地のセルビア系の生 徒によれば，セルビア系住民向けの授業は，言語以外 は歴史も含めクロアチア系住民と同じ内容であるとい う。また，セルビア人教師は，ヴコヴァル郊外のセル ビア系住民居住地域にあるトゥルピニャという集落か ら来ているという（図20）.

そのほかにも，クロアチア紛争時に国外へ逃れたセ ルビア系難民の全てがクロアチアに帰国してはいない ことが問題となっている．セルビア系難民について調 査を行った材木（2009）によると, クロアチアに帰国

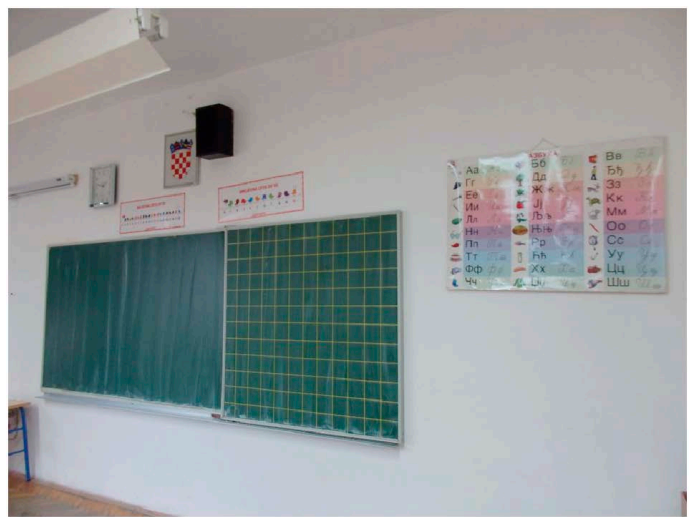

図20 ヴコヴァル市内の小学校にあるセルビア系住 民クラスの様子

(2015年11月 17 日撮影)

Fig. 20 Classroom for ethnic Serbs in a Vukovar elementary school
登録をしたセルビア人 12 万人のうち，実際にクロア チアに戻ったのは 4 万人程度にとどまっている，縞国 を果たしたセルビア系住民の平均年齢は 60 歳以上で あり，経済状況はクロアチア人よりもきわめて悪い状 態にあるという。

こうしたセルビア系住民を取り巻く状況は，クロア チア人を中心としたクロアチアにおいて，マイノリ ティ政策が積極的になされていないことを反映してい る. 一方，ヴコヴァルではセルビア系住民に対して過 度なアファーマティブ・アクションが見られると不満 を漏らすクロアチア人もいた，そして，言語以外はマ イノリティの権利が保障されているならば，文字くら いの権利は小さいことだ，といった権利の保障を無視 したクロアチア人の発言も聞かれた。

百瀬（2017）は，セルビア系住民に対する権利向上 を目指すセルビア民族会議の使命はクロアチア人共同 体との齟齠が生じると想定していた。つまり，クロア チア政府とセルビア系住民に対する権利向上を目指す セルビア民族会議の相反する「祖国戦争」観に妥協の 余地はないため，セルビア系住民の権利に関する制度 面が整備されても, 戦争の「記憶をめぐる認識論的問 題が伏流のように社会の背後に存在している」と指摘 している（百瀬 2017: 221）。まさに上述の現地の語り は，セルビア系住民の権利に対して現れた「認識論的 問題」であり，クロアチア人とセルビア系住民の相互 理解はいまだ十分でないことがわかる．平和的な市民 レベルの共生の道が模索できないまま時間が経過して しまえば，関係修復はより困難になっていくものと思 われる。

2）クロアチア民族政策のダブルスタンダード

クロアチア国内のナショナル・アイデンティティ強 調の動きと, EUの要請による国際化への反応が, クロ アチアのダブルスタンダード，もしくは国内の対立を 生み出していることは，近年日本のバルカン地域の研 究者にも指摘されている。 山川（2015）は「ネイショ ン化」「ヨーロッパ化」という言葉によってクロアチ ア国内で相反した現象が起きていることを説明し，百 瀬（2014）は，二言語表記「推進派」と反キリル文字 運動に現れる「反対派」の対立が国際的な「普遍」へ の適応と, ローカルな事情の「特殊」の二者間に発生 した跙䶣であるとしている。 
これらの指摘と現地での調査の結果を反映させて, クロアチアの現状を考察してみよう.

ナショナル・アイデンティティを強化・継承するこ とによって国民統合を図ってきたクロアチアは, 一方 でヨーロッパの一員となるための EUの要請を受け入 れてマイノリティを保護し，西ヨーロッパ的な国民国 家たろうと努めてきた。 しかしながら，クロアチアは 歴史的な背景からナショナル・アイデンティティを強 化・継承する必要性があった，そこでさまざまな人々 を受け入れ一国民として統合する国民国家であると対 外的にはふるまいながら，国内ではナショナル・マイ ノリティを考慮しない自民族中心の国民国家たる行い が継続されていた，その一つが，ヴコヴァルにおける 戦争記憶の一連のコメモレーションである。つまり, それはアンバランスでありながらも民族主義と多民族 主義が共存している奇妙な状態であるといえる。この ようなダブルスタンダードを生んでしまった背景に, EUが東ヨーロッパの特殊性を十分に理解できていな かったことが考えられよう。すなわち, 紛争時の西側 諸国の介入がユーゴスラヴィアの民族をめぐる混乱を 招き，複雑化させたように，現代もそれと同様の構図 が見られるのである.

クロアチア政府が制定したマイノリティ保護政策 は，特に民族関係がセンシティヴな地域において，現 実との大きなギャップに直面していることが明らかに なった. 法改正によって形式的にマイノリティが保護 されるようになったことになり，弱い立場にいるマイ ノリティの姿は以前より見えなくなっているといえ る. 一方, マジョリティであるクロアチア人は,「十 分な権利を受けている」としてセルビア系住民に対し て不満をもつなど, 紛争後の両民族の関係改善は思う ように進んでいない状態である. クロアチア憲法裁判 所の決定はナショナル・マイノリティであるセルビア 人を勇気づけるものであったが，憲法裁判所のあるザ グレブから遠く離れたヴコヴァルでは，この決定の後 もキリル文字に対して大きな反発が生じており，二か 国語表記の動きは順調に進んでいない.いまだ紛争の 憎しみが消えない地方の現場では，素直にザグレブの 決定を受け入れらないマジョリティが多くいる.クロ アチアという国家は, 当初クロアチア人中心の国家と して歩み始めたが，時代の要請に応えてナショナル．
アイデンティティの強化・継承の在り方を変化させて いくべきであろう。そうしなければ，平和的な民族の 共生と和解の道は市民レベルにおいても困難になり, このままの状態が続けばマジョリティとマイノリティ の間で社会の分断が生じてしまうと予想される。ヴコ ヴァルのセルビア系住民に対してインタビューを行っ た際，クロアチアのEU加盟前後からセルビア系住民 に対して，一部のクロアチア人によるへイトスピーチ が増加している実感があるという話があった．統計的 なデータではないが, ナショナル・マイノリテイがこ のような実感を抱いている点は看過できない.クロア チアでこのようなダブルスタンダードの体制が今後も 継続されるならば，同様に多くの民族問題を抱える東 ヨーロッパ諸国の社会，ひいては $\mathrm{EU}$ 全体にも深い亀 裂を生むような影響を生じることになりかねない.

\section{V おわりに}

本稿は, クロアチアにおける戦争記憶の表象に着目 することによって，ナショナル・アイデンティティの 強化と継承を行う理由を解明し，なぜクロアチアでは 民族が重視されるのか，そしてクロアチアにおける民 族が絡んだ問題はどのようなものであるか，その一端 を明らかにした。 ナショナル・マジョリティであるク ロアチア人の側からだけでなく，マイノリティである セルビア系住民の側も対比しながら描くことによっ て, クロアチアで進行しているナショナル・アイデン ティティの強化と継承について論じた.

EUによるナショナル・マイノリティ保護の要請に 応えたクロアチア政府は，クロアチアがクロアチア人 主体の国家であるという内実を抱えつつ，西ヨーロッ パ的な国民国家を目指したがゆえに，マイノリティの 処遇を巡ってダブルスタンダードを生んだ。このダブ ルスタンダードの状態が続けば，クロアチアにおける マジョリティとマイノリティの分断が生じるであろ う。しかしながら，自国第一主義が世界で台頭するな かで，憲法裁判所がセルビア人マイノリティの権利を 認める決定を下したことは画期的であり，後退してい たクロアチアのマイノリティ保護政策の大きな一歩と して考えられる.

本稿では，複雑な民族的背景を抱える東ヨーロッパ 
と，東ヨーロッパヘと拡大した EU，それぞれが抱え る現在の問題を念頭に置いた検討も行った，今後どの ような展開になるのか予測は難しいが, 政治レベルで の早期の和解と歩み寄り強く望まれる.

最後に，政治レベルではこのような民族間の溝ばか りが強調されるが，愛国的な国家の動きとは別に，市 民レベルではさまざまな民族共生の運動が起きている ことも見過ごせない，実際，ヴコヴァルでも，一部の 市民団体が民族を超えた協力や理解を図るためのワー クショップを行っている. 彼らの地道な活動が, 国家 の意図するものとは別の形で民族理解を育む一助にな る.このような市民の「希望をもった」草の根運動に ついても, 今後目を向けていきたい.

\section{謝 辞}

本稿は，2016年に東京学芸大学大学院総合教育開 発専攻地域研究教育サブコースに提出した修士論文 を，大幅に修正・加筆したものである.

フィールド調查でお世話になった方々，また日本で 筆者の研究に御協力いただいた全ての方々に打礼申し 上げます，現地ではクロアチア人とセルビア系住民共 に，さまざまな体験を聞かせていただきましたそそこ に眠る人たち，まだ見つからない人たちも含めて，心 より感謝いたします。

本稿の一部は, 2018 年日本地理学会春季学術大会 に扔いてエスニック地理学研究グループで発表した.

\section{注}

1）EU加盟国だが，通貨は独自通貨のクーナを使用 する。また，シェンゲン協定は実施していない．

2）2011年国勢調査による.

3） 1925 年には，中世クロアチア王国の「千年祭」が 開催された。

4）第二次世界大戦の「兄弟殺し」の記憶は，1990年 代のユーゴスラヴィア紛争で再び持ち出され，ク ロアチア，セルビアは共に，第二次世界戦時中に 起きた双方の残虐行為をプロパガンダとして利用 した.

5）クロアチア人の歴史家，政治家（1922１999年). ユーゴスラヴィア人民軍退役後, 1971年の「ク ロアチアの春」では民族主義的な言動が問題とな
り，ユーゴスラヴィア政権下で投獄される。1990 年にはHDZの党首として臨んだ選挙に大勝, ク ロアチア独立の立役者となる。「クロアチア建国 の父」ともいわれるが，その民族主義者としての 過激なまでのふるまいのため, 彼の死後その評価 は見直されている。

6）クロアチア語とセルビア語はアクセントや一部単 語が異なる以外，きわめて類似した言語である. ただし，クロアチア語はラテン文字（ヴコヴァル はVukovar)，セルビア語はキリル文字（同じく Вуковар）を使用するため，表記されることによっ て両言語の違いは明確になる。1990年7月にはセ ルビア人が多く住む地域でもラテン文字使用の義 務化が決定された。

7）なお，この点について月村 $(2007: 47,48)$ は，実 際にクロアチア東部に住むセルビア系住民の当時 の心理状態を，「ある程度の規模の住民が縓まり つつ入り交って居住している場合（混住）は，民 族的多数派からの攻撃を受けるのではないかとい う恐怖が生ずる可能性が非常に高い」という「民 族的少数派」となる恐怖として説明している.

8）郡を構成する単位の一つで, 市よりも小規模なも の.

9）もっとも，ヴコヴァルには何世代にもわたって長 く定住しているセルビア系住民と，定住の歴史が 比較的浅いセルビア系住民の二つのパターンがあ るため, 第一波のセルビア系住民を考慮すれば, ヴコヴァルのセルビア系住民がクロアチア系住民 と共存できていなかったとは一概にいえないだろ う.

10）一方, 戦時中JNAはヴコヴァル内のセルビア人 居住区をあらかじめ把握していたため，その地区 はJNAの被害を受けることはなかった，真新し い家々が立ち並ぶヴコヴァル市内には老朽化した 家屋の多い地区も残されているが，その多くはセ ルビア人居住地区である。

11）ヴコヴァル在住のセルビア系住民であり，セルビ ア系住民向け新聞 izborの編集長スラヴコ・ブバ ロ氏による，また，夫または妻がセルビア人の場 合，本人がクロアチア人であっても，連れ去られ て行方不明になったり，殺害されたりするケース 
があったという。

12）アルブヴァクスによれば，石造物の物質的な永続 性が集合的記憶に寄与しているという（アルブ ヴァクス 1989).

13）フランスの歴史学者ノラが提唱した「記憶の場」 とは，「平等で均質な個人しか認めようとしない 社会における，帰属集団を見分けるしるし」であ り, 物質的・象徴的・機能的な要素をもっている 場を意味する（ノラ 2000）.

14）チェトニクとは本来, 第二次世界大戦時のセルビ ア民族主義に基づく反ファシズム組織を指すが, 1990 年代の紛争で一部のセルビア軍はチェトニ クと自称した.

15）たとえば祖国戦争教育の教科書（Barič et al. 2015） の表紙には, 給水塔の写真が載っている.

16）クロアチアの初等教育は 8 年, 中等教育は $3 \sim 4$ 年 である。

17）メモリアルセンターホームページによる.

18）ちなみに警察音楽隊の唱歌では, ヴコヴァルのあ るスラヴォニア地域とは全く関連性のない, ダル マティア地方の伝統的な男性混声合唱であるグ ラッパも披露されていた。

19）祝日とはなっていないが，1999年クロアチア議会 はこの日を「1991年ヴコヴァル犠牲者を想起する 日」として記念日に制定した（百瀬 2014: 167）.

20） 2016 年 11 月 18 日の参加者数は, クロアチア日刊紙 ヴェチェルニイリストのウェブサイト記事による. Večernji List, Kolona sjećanja: Gotovo 100 tisuća ljudi u Vukovaru, Gra-bar-Kitarović hodala s 'djevojčicom u plavom ka-putiću' (released 18 Nov. 2016) http://www.vecernji.hr/hrvatska/najvecu-cast-onimakoji-su-umrli-za-nasu-slobodu-cinimo-borbom-za-srecuonih-koji-su-prezivjeli-1129369 (last accessed 9 Jan. 2017)

2019 年 11 月 18 日の参加者数は, クロアチア国内紙 Dnevnikのウェブサイト記事による。 DNEVNIK. hr, Piše D.I: Tisuće ljudi u Vukovaru i Škabrnji: Niz Dunav pušteni vijenci i 700 lampiona, kao tužno sjećanje na sve žrtve u Domovinskom ratu (released 11 Nov. 2019)

https://dnevnik.hr/vijesti/hrvatska/krsticevic-u-skabrnji- hrvatsku-danas-cuva-mocna-vojska-kako-se-ovakvizlocini-nikada-ne-bi-ponovili-583530.html (last accessed 20 Dec. 2019)

21）「ヴコヴァル通り」を意味するVukovarski ulicaま たはUlica Grada Vukovaraは，2019年7月3日時点 でクロアチア国内に61 カ所確認できた。 ただし， これらの通り全てで追悼式が行われているかは確 認できなかった.

22）ただし，それが国内各地の地域的な組織と関連し たものかどうかは確認できなかった.

23）スラヴコ・ブバロ氏への聞取りによる.

24）6月28日は「ヴィドヴダン」という聖ヴィトゥス にちなんだセルビア正教会の聖者を祭る日である と同時に, 1389年にコソヴオの戦いでオスマン 帝国に敗れた中世セルビア王国が領土を失った日 であり, セルビア人にとってきわめて重要な日で ある。

25）ヴコヴァルのセルビア人遺族団体の代表のスロボ ダン・ヤコヴリェヴィチ氏の聞取りによる。彼は 紛争前に父親をクロアチア人の襲撃によって亡く した，遺族団体の規模は小さく，七ルビア人犠牲 者の数に比べて加盟者は少ないという.

26）ノラは『記憶の場』において, 彫像や戦没者慰霊 碑などのモニュメントも（記憶の）場となり，そ のような場の意義は内在的な存在であると指摘し ている（ノラ 2002: 35).

27）ヴコヴァルにおける反キリル文字運動について は, クロアチアの EU加盟を見据えた動きを論じ た百瀬（2014）が詳しい.

28）毎年 11 月 18 日に個人商店を閉めるセルビア人が 1 件確認できた。マジョリテイの戦争記憶が強化 され，継承されるコメモレーションに直面する と, セルビア人はこうした小さな抵抗，もしくは 自己防衛をしている.

29）たとえば石田（2000：12）は『記憶と忘却の政治 学』で,「記憶という行為はある側面の忘却, そ して別の側面の想起によって現在の立場から過去 を再構成し，それによって未来への行為を意味づ ける作用をもつ」と指摘している。つまり，「記 憶は過去と未来の間にある行動主体が，現在にお いて行なう…選択を伴う行為」となる。 この石田 
の記憶に関する考えは, ルナンがからて「国民の 存在とは日々の人民投票」と例えたことに通じて いよう（ルナン 1997: 62）.

30）近代のクロアチアの国土は, ダルマティアの大部 分をヴェネッィアに, ボスニアの大部分をオスマ ン帝国に支配され，中世クロアチア王国から各地 域が分断された「残部の残部」となった歴史があ る.

31）1941年クロアチアのファシズム組織ウスタシャ が中心となって成立したナチス・ドイツの傀儡国 家．国家の領域はボスニア・ヘルツェゴヴィナ全 土を含んでおり，それは中世クロアチア王国と最 大版図と同等であった.

32）クロアチアのスラヴォニア地方の一部にあるスレ ム地域は, ドナウ川とサヴァ川の間にあり，七ル ビア人とクロアチア人の混住地域であった，スレ ム地域は, 東部はセルビア共和国のヴォイヴオ デイナ自治州に，西部はクロアチア共和国に分割 された，独立後のクロアチアの歴史教科書では, ユーゴスラヴィアによる国境策定でのスレム地域 の衰失が強調されている（石田 2011: 6).

33）これは「クロアチア問題」として第一のユーゴス ラヴィア内でくすぶり続けた，この問題は「南ス ラヴの統一国家の中に，長年にわたり異なる歴史 的経緯をたどってきたセルビア王国の領域とクロ アチアの領域とが結びっけられることによって, 必然的に引き起こされたといえる」(柴 1996: 63).

34）クロアチア独立国が，自民族をスラヴ民族から峻別 し，セルビア人の虐殺を行ったことについては， 「西洋への帰属を望む願望の裏返しでもあった」 という見解（清水 2007）もある.

35）スラヴォニアのセルビア人マイノリティを対象に している地方新聞izborは，2007年に創刊されて いる.

36）1996年 9 月 9 日クロアチア共和国は隣国セルビア 共和国と外交関倸を樹立し，これを契機にクロア チア国内にセルビア領事館が設置された。領事館 は国内のセルビア系住民の権利保護に重要な拠点 となった、なお，七ルビア共和国とは，クロアチ ア紛争の戦争犯罪に関する解釈の違いで対立が現
在も続いている．毎年11月に行われる追悼記念 行事では, 郊外の墓地まで徒歩で歩くルートの途 中にセルビア領事館があり，2015年イベント参 加時には領事館の前を数名の警官が警戒に当たっ ていた，領事館に向かってつばを吐きかける者の 姿も確認できた。

37) B92, Croatian town's removal of Serbian Cyrillic "clear message” (released 17 Aug. 2015): http://www.b92.net/ eng/news/region.php?yyy $=2015 \& \mathrm{~mm}=08 \& \mathrm{dd}=17 \&$ nav_id=95124（last accessed 28 Dec. 2019）による.

38) B92, EU: Cyrillic issue in Vukovar not in our competence (released 19 Aug. 2015)

http://www.b92.net/eng/news/politics.php?yyyy=2015 $\& \mathrm{~mm}=08 \& \mathrm{dd}=19 \&$ nav_id $=95141$ (last accessed 10 Jan. 2017）による.

Council of Europe, Council of Europe supports use of minority languages in public signs (released 21 Aug. 2015)

https://www.coe.int/en/web/portal/home/-/asset_publi sher/CWAECqDHgT3y/content/council-of-europesupports-use-of-minority-languages-in-public-signs?in heritRedirect=false\&redirect=http $\% 3 \mathrm{~A} \% 2 \mathrm{~F} \% 2 \mathrm{Fwww}$. coe.int $\% 2$ Fen\%2Fweb\%2Fportal\%2Fhome\%3Fp_p id\%3D101_INSTANCE_CWAECqDHgT3y\%26p_p_ lifecycle\%3D0\%26p_p_state\%3Dnormal\%26p_p mode\%3Dview\%26p_p_col_id\%3Dcolumn-2\%26p p_col_count\%3D1 (last accessed 28 Dec. 2019) に よる.

39）ヴコヴァル市議会の決定は, 国内外で批判を呼ん だ. ヨーロッパ評議会は少数民族の権利保護の観 点から懸念を表明した.クロアチア国内でも当時 のイヴオ・ヨスイポヴィチ大統領やヴコヴァルの ジェリコ・サヴオ市長でさえ反対の立場を取った。 なお，上記の 2 名は中道左派の SPD（クロアチア 社会民主党）に所属している。2013年11月の条 約改正では,「「祖国戦争」関連施設へのキリル文 字の導入は例外的に避けられ」(百瀬 2014: 182) る措置がとられたが，翌年2014年 6月にサヴォが 僅差でHDZ所属のイヴァン・ペナヴァに市長の 座を明け渡して以降, ヴコヴァルに打ける公共施 設でのキリル文字禁止の動きが加速した。 


\begin{abstract}
クロアチア憲法裁判所の決定に関しては, クロア チアのテレグラム紙および独立民主セルビア人党 （SDSS）の記事を参照した。
\end{abstract}

Ustavni sud donio je važnu presudu: Srbi u Vukovaru dobivaju veća prava na svoj jezik i pismo (released 12 Jul. 2019)

https://www.telegram.hr/politika-kriminal/ustavni-suddonio-je-vaznu-presudu-srbi-u-vukovaru-dobivaju-vecaprava-na-svoj-jezik-i-pismo/ (last accessed 29 Dec. 2019)

Ustavnu sud: Vlast u Vukovaru mora povećati prava srpske manjine! (released 12 Jul. 2019)

http://sdss.hr/ustavnu-sud-vlast-u-vukovaru-morapovecati-prava-srpske-manjine/ (last accessed 29 Dec. 2019)

\section{文 献}

アルヴァックス， M. 著，小関藤一郎訳 1989.『集合 的記憶』行路社.

Halbwachs, M. 1950. La mémorie collective. Paris: Presses Universitaires de France.

粟津賢太 2000. ナショナリズムとモニュメンタリズ ム——英国の戦没記念碑における伝統と記憶. 大谷 栄一・川又俊則・菊池裕生編著『構築される信念 一宗教社会学のアクチュアリティを求めて』113131. ハーベスト社.

粟津賢太 2006. 集合的記憶のポリティクス——沖縄 におけるアジア太平洋戦争後の戦没者記念施設を中 心に. 国立歴史民俗博物館研究報告 126: 87-118.

アンダーソン, B. 著, 白石 隆・白石さや訳 2007. 『定本 想像の共同体—ナショナリズムの起源と 流行』書籍工房早山. Anderson, B. 2006. Imaging communities: Reflections on the origin and spread of nationalism (1991 Revised and Expanded edition). Verso.

石田信一 2003. クロアチアの地方制度とマイノリ ティ問題. 跡見学園女子大学文学部紀要 36: 1-16.

石田信一 2011. 歴史教科書におけるユーゴスラヴィ ア連邦時代の評価をめぐって．跡見学園女子大学文 学部紀要 46: 1-14.

石田 雄 2000.『記憶と忘却の政治学—同化政策 · 戦争責任・集合的記憶』明石書店.

久保慶一 2003。『引き裂かれた国家一一旧ユーゴ地域 の民主化と民族問題』有信堂高文社.

コレン, S. 著, 百瀬亮司訳 2008. 教科書のなかの地 域史一クロアチアの事例. 柴 宜弘編『バルカン 史と歴史教育——地域史」とアイデンティテイの 再構築』120-139. 明石書店.

材木和雄 2009. クロアチアにおける民族問題とセル
ビア人の地位—その歴史的変遷と内戦終結後の問 題状況. IPSHU研究報告シリーズ 42: 118-143.

定形 衛 2001. 旧ユーゴスラヴィア終焉の諸相— 連邦・民族・国際社会（焦点旧ユーゴスラヴィア の 10 年). 国際問題 496: 2-14.

定形 衛 2006. 西バルカンEU/NATO. 羽場久美子 . 小森田秋夫・田中素香編『ヨーロッパの東方拡大』 295-312. 岩波書店.

柴 宜弘 1996.『ユーゴスラヴィア現代史』岩波書 店.

清水明子 2007.「クロアチア独立国」におけるセルビ ア人虐殺 (一九四一〜四二年). 松村高夫 · 矢野 久編著『大量虐殺の社会史』93-111. ミネルヴァ書 房.

関沢まゆみ 2010.「戦争と詩」の記憶と語り——フ ンスの二つの事例より。関沢まゆみ編『戦争記憶論 忘却, 変容そして継承』159-183. 昭和堂.

月村太郎 2006.『ユーゴ内戦一一政治リーダーと民族 主義』東京大学出版会.

月村太郎 2007. 民族的少数派となる恐怖一一旧ユー ゴ連邦解体過程におけるセルビア人を例として（周 縁からの国際政治)。国際政治 149: 46-60.

ノラ，P. 著，長井伸仁訳 2000．記憶と歴史のはざま に一一記憶の場の研究に向けて（記憶の場）。思想 911: 13-37. Nora, P. 1996. Entre Mémorie et Historie: La problématique des lieux. Paris: Éditions Gallimard.

ノラ, P. 編, 谷川 稔訳 2002.『記憶の場』から『記 憶の領域』へ. ノラ, P. 編, 谷川 稔監訳『対立』 15-28. 岩波書店. Nora, P. 1996. From Lieux de mémoire to Realms of Memory. Realms of Memory: Rethinking the French Past, vol. 1. New Your: Columbia University Press.

フット, K. E. 著, 和田光弘ほか訳 2002. 『記念碑の 語るアメリカ一一暴力と追悼の風景』名古屋大学出 版会. Foote, K. E. 1997. Shadowed ground: America's landscape of violence and tragedy. Austin: University of Texas Press.

ボドナー，J. 著，野村達朗ほか訳 1997。『鎮魂と祝祭 のアメリカ一一歴史の記憶と愛国主義』青木書店. Bodner, J. 1992. Remaking america: Public memory, commemoration, and patriotism in the twentieth century. Princeton University Press.

マリタ・スターケン著, 岩崎稔ほか訳（2004）『アメ リカという記憶——゙トナム戦争, エイズ, 記念碑 的表象』未來社. Sturken, M. (1997). Tangled memories: The Vietnam War, the AIDS epidemics, and the politics of remembering. Berkeley: University of California Press.

モッセ, G. L. 著, 宮武実知子訳 2002.『英霊—創 られた世界大戦の記憶』柏書房. Mosse, G. L. 1990. Fallen soldiers: Reshaping the memory of the World Wars. London: Oxford University Press.

百瀬亮司 2017. クロアチア多民族社会におけるセル ビア人の自決権——領域的自治の限界か文化的自治 
のジレンマ. 山本明代 /パプ・ノルベルト編『移動 がつくる東中欧・バルカン史』193-227. 刀水書房.

百瀬亮司 2014. ヴコヴァルの反キリル文字運動と 「記憶」の双極化. ことばと社会 (多言語社会研究) 16: 160-190.

山川 卓 2015. 独立以降のクロアチアにおけるマイ ノリティ問題——ネイション化」と「ヨーロッパ 化」をめぐる難民政策の変容. 立命館国際関係論集 12: $153-176$.

ル ゴフ, J. 著, 立川孝一訳 1999.『歴史と記憶』法 政大学出版局. Le Goff, J. 1988. Histoire et mémoire. Paris: Gallimard.

ルナン, E. 著, 鵜飼 哲訳 1997. 国民とは何か.ル ナン，E．ほか著・鵜飼 哲ほか訳『国民とは何か』 41-64. 河出書房新社. Renan, E. 1987. Qu'est-ce qu' une nation? Paris: Euvres Complètes.

和田光弘 2005. 記念碑の創るアメリカ一一最初の植 民地・独立革命・南部. 若尾祐司，羽賀祥二編『記 録と記憶の比較文化史一一史誌 - 記念碑 - 郷土』 114-164. 名古屋大学出版会.

Barič, N. et al. 2015. Domovinski Rat-čitanka priručnik za učitelje povijesti u osnovnim školama i nastavnike povijesti u srednjim školama. Zagreb: Školska knjiga, d.d. (クロアチア語)

Croatian Homeland War Memorial and Documentation Centre 2011. The town was the target: The hospital, the nursing home... Zagreb: Croatian Homeland War Memo- rial and Documentation Centre.

Marič, R. 2005. Vukovar. Zagreb: Turistička naklada d.o.o. Minority Rights International 2003. Minorities in Croatia. London: Minority Rights International.

Nazor, A. 2011. Velikosrpka Agresija na Hrvatsku 1990-ih/ Greater-Serbian Aggression against Croatia in the 1990s (The Republic of Croatia and the Homeland War: Overview of Political and Military Developments 1990, 19911995/1998). Zagreb: Croatian Homeland War Memorial and Documentation Centre（英語・クロアチア語）.

ヴコヴァル市. http://www.vukovar.hr/（最終閲覧日： 2019年2月17日)

ヴコヴァルメモリアルセンター。 http://www.mcdrvu. hr/index.php/en/（最終閲覧日：2019年2月25日）

外務省, クロアチア共和国基礎データ. http://www. mofa.go.jp/mofaj/area/croatia/data.html（最終閲覧日： 2019年2月 25日)

クロアチア統計局. http://www.dzs.hr/default_e.htm（最 終閲覧日：2019年2月25日)

Eurostat Statistics Explained, Unemployment statistics (released Dec. 2018). https://ec.europa.eu/eurostat/statisticsexplained/index.php/Unemployment_statistics\#Recent_ developents_in_unemployment_at_a_European_and Member_State_level (last accessed 25 Feb. 2019)

Place of Memory Vukovar Hospital. http://www.ob-vukovar. $\mathrm{hr} /$ mjesto-sjecanja/mjesto-sjecanja.htm (last accessed 25 Feb. 2019)

\section{〈著者略歴〉}

木戸 泉（きど いずみ）

1990 年千葉県生まれ. 東京学芸大学大学院総合教育開発専攻地域研究教育サブコース修了. 現在建設コンサル タント勤務. 学術修士. 